\title{
The evidence on tiotropium bromide in asthma: from the rationale to the bedside
}

\author{
Dejan Radovanovic ${ }^{1}$, Pierachille Santus ${ }^{1}$, Francesco Blasi ${ }^{2}$ and Marco Mantero ${ }^{2^{*}}$ (D)
}

\begin{abstract}
Severe and poorly controlled asthma still accounts for a great portion of the patients affected. Disease control and future risk management have been identified by international guidelines as the main goals in patients with asthma. The need for new treatment approaches has led to reconsider anticholinergic drugs as an option for asthma treatment. Tiotropium is the first anticholinergic drug that has been approved for children and adults with poorly controlled asthma and is currently considered as an option for steps 4 and 5 of the Global Initiative for Asthma. In large randomized clinical trials enrolling patients with moderate to severe asthma, add-on therapy with tiotropium has demonstrated to be efficacious in improving lung function, decreasing risk of exacerbation and slowing the worsening of disease; accordingly, tiotropium demonstrated to be non inferior compared to long acting beta-agonists in the maintenance treatment along with medium to high inhaled corticosteroids. In view of the numerous ancillary effects acting on inflammation, airway remodeling, mucus production and cough reflex, along with the good safety profile and the broad spectrum of efficacy demonstrated in different disease phenotypes, tiotropium can represent a beneficial alternative in the therapeutic management of poorly controlled asthma. The present extensive narrative review presents the pharmacological and pathophysiological basis that guided the rationale for the introduction of tiotropium in asthma treatment algorithm, with a particular focus on its conventional and unconventional effects; finally, data on tiotropium efficacy and safety. from recent randomized clinical trials performed in all age categories will be extensively discussed.
\end{abstract}

Keywords: Airway remodeling, Anticholinergic, Asthma, Exacerbation, Forced expiratory flow, Inflammation, Muscarinic receptor, Poor control, Tiotropium

\section{Background}

Asthma is a chronic inflammatory disease of the airways characterized by a complex pathophysiology and caused by different etiological factors which contribute to the heterogeneity of clinical presentation and to the severity of disease. Asthma can manifest both in childhood and in elderly patients [1], the number of patients affected worldwide being estimated in 235 million [2], ranging from 1 to $18 \%$ of the population in different countries [3]. Asthma is characterized by a variable combination of symptoms such as wheeze, cough, shortness of breath, chest tightness and by different degrees of airflow obstruction and airway hyper-responsiveness that can vary in time and intensity $[3,4]$. The worsening of respiratory

\footnotetext{
* Correspondence: marco.mantero@unimi.it

${ }^{2}$ Department of Pathophysiology and Transplantation, University of Milan,

Cardio-thoracic unit and Adult Cystic Fibrosis Center, Fondazione IRCCS Ca'

Granda Ospedale Maggiore Policlinico, Milan, Italy

Full list of author information is available at the end of the article
}

symptoms and thus disease exacerbations can be caused by direct or mediated mechanical, physical and infectious stresses that increase bronchial inflammation and cause an acute worsening of airflow obstruction [3]. The latter circumstance, especially in elderly patients, can be complicated by comorbid conditions requiring a multidisciplinary therapeutic approach [5, 6]. Poor control of symptoms and acute exacerbations requiring emergency room admittance and hospitalization expose patients to a poor quality of life, high mobility and a significant economic burden on the healthcare system and society [7]. Although to a minor extent compared with chronic obstructive pulmonary disease (COPD) $[8,9]$, severe and poorly controlled asthma still accounts for a significant in-hospital mortality, especially in children, elderly and mechanically ventilated patients $[10,11]$, or patients from low income countries [2]. For many years, important efforts have been spent to optimize asthma management; 
however, despite the availability of new treatment options [12], international surveys continue to provide evidence for suboptimal asthma control in many countries [13], with poor control of symptoms and exposure to risk of exacerbation in some cases affecting more than $50 \%$ of patients $[14,15]$. The need for new treatment approaches has led to reconsider anticholinergic drugs as a pharmacological treatment option for asthma [16]. While also other muscarinic antagonists are currently being considered for approval in asthma [16], the only anticholinergic drug introduced so far in the treatment algorithms of major international guidelines is represented by tiotropium bromide. In the last few years numerous clinical trials proved the efficacy of tiotropium both in adult and younger patients for the chronic treatment of asthma. Due to the numerous non-bronchodilator properties expressed by tiotropium, its efficacy may not completely rely on the reduction of the airways' cholinergic bronchomotor tone, but also on anti-inflammatory and modulatory effects of the structures involved in the complex molecular and cellular pathophysiology of asthma. The aim of the present extensive narrative review is to highlight the pharmacological and non-bronchodilator properties of tiotropium and to present the data of clinical trials conducted so far to examine its role in connection with the current pharmacological treatment paradigm in patients with asthma.

\section{The rationale for anticholinergic drugs in asthma The cholinergic system in human airways}

The innervation of human airways is mainly represented by the parasympathetic system [17]. The sympathetic system is less represented, however, some sympathetic endings can be found on ganglion cell bodies and, therefore, may be involved in the modulation of cholinergic traffic $[18,19]$. Acetylcholine $(\mathrm{ACh})$ is the major neurotransmitter of the parasympathetic nervous system and acts both at the ganglionic transmission and the neuroeffector junctions [16, 18]. ACh has two classes of receptors: nicotinic and muscarinic. The first are ligandgated ion channels, mainly present on the peribronchial ganglion; muscarinic receptors are G-protein-coupled receptors and more widely distributed in the lung [19]. Bronchoconstriction is primarily regulated by muscarinic receptors $\left(M_{R}\right)$; of the five receptor subtypes, $M_{1}, M_{2}$ and $M_{3}$ are expressed in the lung and in the bronchial tree. $M_{1 R}$ are mainly distributed in the peripheral lung tissue and in the alveolar walls [16] within parasympathetic ganglia and regulate cholinergic transmission [20]. $\mathrm{M}_{2 \mathrm{R}}$ are found in post-ganglionic nerves where they serve as auto-receptors, on smooth muscle cells (SM) where they are coupled to inhibitory G-proteins $[16,21]$ and on fibroblasts [16]. Together with $\mathrm{M}_{2 R}, \mathrm{M}_{3 R}$ are the most represented in human airways; they are predominantly expressed in SM cells and mediate SM ACh-induced contraction $[16,20]$. In central airways this mechanism is mediated by vagal innervation, in the periphery of the lung $\mathrm{M}_{3 \mathrm{R}}$ function is mediated by $\mathrm{ACh}$ released in response to inflammatory stimuli from epithelial cells expressing choline acetyl-transferase (ChAT) [16]. $\mathrm{M}_{3 \mathrm{R}}$ serve also as mediators of airways blood vessels and can be found in sub-mucosal glands where they are responsible for mucus secretion [22].

Although in normal conditions adrenergic sympathetic, cholinergic and non-cholinergic parasympathetic nerves are all active, vagal innervation is considered the major determinant of airways' tone [22] and is regarded as the major reversible pathophysiological mechanism responsible for airflow obstruction in COPD. In asthma, an up-regulated release of $\mathrm{ACh}$ causes an increased bronchial tone, bronchial hyper-responsiveness and reflex bronchoconstriction [23] which in turn contribute to the narrowing of the airways causing respiratory symptoms and eventually asthma exacerbations. The accurate reason for an increased ACh activity is still unknown, but it has been postulated to derive from an increased susceptibility of the cholinergic system, increased intracellular signaling of muscarinic receptors or by activation of prejunctional facilitatory receptors on cholinergic nerve endings, leading to up-regulated synthesis through higher activity of ChAT or by reduced degradation through choline-esterases [24].

In parallel to the vagal-mediated ACh production, the non-neuronal cholinergic system has an important regulatory role in the homeostasis of airway cells. ACh is responsible for numerous cell vital functions as cell-cycle, proliferation, differentiation, migration and chemokinesis [21]. Increasing evidences suggest that in the airways, non-neuronal ACh can affect several transduction pathways such as G-proteins, phospholipase C, effector kineses, classical and non selective ion and cation channels, and large conductance voltage and calciumactivated potassium channels [21]. Although in some cases cholinergic effects may be produced by mediators other than $A C h$ on $M_{R}$ [21], almost every cell type present in the airways expresses components of the cholinergic system, such as $\mathrm{M}_{R}$, ChAT, the high affinity choline transporter (CHT-1), as well as ACh itself [24]. Non-neuronal production of ACh could be particularly relevant in peripheral airways, where cholinergic innervation is scarce. A production of non-neuronal ACh may also be responsible, together with the parasympathetic vagal system, in the modulation of the bronchomotor tone, both in basal conditions and in a disease-state [21]. Given these evidences, the blockade of $M_{R}$ by cholinergic antagonists may not always seem beneficial. The effect will rely mostly on drug's specific receptor selectivity, kinetics, dynamics and on the molecules the cholinergic antagonists interact with. In asthma, the usual regulatory role of 
$\mathrm{M}_{2 \mathrm{R}}$ can be overcome by eosinophil release during allergen-challenges, while $M_{2 R}$ in some cases can also be dysfunctional [25]. An increased activation of $\mathrm{M}_{3 \mathrm{R}}$ by $\mathrm{ACh}$ during airway inflammation states has an effect on SM remodeling, mucus production and the fostering of the inflammatory response [26]. Although it is still not clear if an increased parasympathetic tone is due to the inflammatory state present in asthma or represents a pathophysiological mechanism by itself, the rationale for the application of cholinergic antagonists in asthma appears robust $[16,20]$ and the non-neuronal cholinergic represents a favorable target.

\section{Unmet needs in asthma}

To obtain and maintain disease control, until 2015, long acting $\beta 2$-agonists (LABA) represented the only inhaled bronchodilator treatment in international guidelines, which recommended a stepwise approach according to which LABA in association with inhaled corticosteroids (ICS) at low doses were added beginning from step 3, to be increased in step 4 and 5 [27, 28]. In the last decade the paradigm of asthma control has been evolving along with the increased awareness that any intervention employed to obtain the disease control should consider the management of patients' future risk [29, 30]. The latter should include, among others, the minimization of adverse events while providing the optimal treatment coverage, the prevention of lung function decline and reduced lung growth in children and, most importantly, the prevention of recurrent exacerbation and especially severe relapses leading to emergency department access and hospitalization $[4,30]$. Major risk factors related to future exacerbations are represented by a previous history of exacerbations, increased use of oral corticosteroids and rescue medications, obesity, worse lung function, poor adherence to inhaled therapy, low Asthma Control Questionnaire (ACQ-7) score, co-morbid diseases, chronic sinusitis and cigarette smoke (Table 1) [3, 31-43]. Despite poor inhaler technique has been demonstrated to be related to worse asthma control [44, 45], most of the analyses designed to evaluate risk factors predictive of future exacerbations did not include it in the regressions [37]. The definition of full control in international guidelines includes the use of reliever medication less than twice a week, having no limitation in daily life activities, normal lung function and absence of nocturnal symptoms [3]. Despite this approach, and the numerous pharmacological and clinical interventions now available, there is frequently a misperception of asthma control among patients [40]. In a recent multicenter European study involving more than 8,000 patients, sub-optimal asthma control was found in $56.2 \%$ of patients [38], while in a large cohort of patients that followed a guideline-derived asthma control management [15], although the majority of patients treated with
Table 1 Factors associated with increased risk of poor asthma control in adults and the pediatric population

\begin{tabular}{|c|c|c|}
\hline Determinants for poor control & Pediatric & Adults \\
\hline \multicolumn{3}{|l|}{ Clinical and functional } \\
\hline $\begin{array}{l}\text { Exacerbations in the previous year } \\
\text { (previous } 12 \text { months) }\end{array}$ & $x$ & $x$ \\
\hline $\begin{array}{l}\text { Hospitalizations in the previous year } \\
\text { (previous } 12 \text { months) }\end{array}$ & $x$ & $x$ \\
\hline Respiratory infections (previous 12 months) & $x$ & \\
\hline Oral corticosteroid use (previous 12 months) & $x$ & $x$ \\
\hline SABA prescriptions ( $1 \times 200$ dose canister/month) & & $x$ \\
\hline Healthcare utilization & $x$ & $x$ \\
\hline Poor lung function & & $x$ \\
\hline Sputum or blood eosinophilia & & $x$ \\
\hline Variability of asthma control & $x$ & $x$ \\
\hline ACQ-7 $<15$ & $x$ & $x$ \\
\hline \multicolumn{3}{|l|}{ Demographic } \\
\hline Female & & $x$ \\
\hline Age (40 to 64 years old) & & $x$ \\
\hline \multicolumn{3}{|l|}{ Comorbidities } \\
\hline GERD & & $x$ \\
\hline Obesity & $x$ & $x$ \\
\hline Overweight & & $x$ \\
\hline Low birth weight & $x$ & \\
\hline OSA-sleep disordered breathing & $x$ & $x$ \\
\hline Allergic rhinitis & $x$ & $x$ \\
\hline Congestive heart failure & & $x$ \\
\hline Drug exposure & & $x$ \\
\hline \multicolumn{3}{|l|}{ Psychological } \\
\hline Anxiety and depression & & $x$ \\
\hline Misperception of disease & $x$ & $x$ \\
\hline Low expectations & & $x$ \\
\hline Poor knowledge of disease & $x$ & $x$ \\
\hline Parent related severity of disease & $x$ & \\
\hline \multicolumn{3}{|l|}{ Patient-independent } \\
\hline Doctor-related attitudes & & $x$ \\
\hline \multicolumn{3}{|l|}{ Patient-dependent } \\
\hline Weight gain & & $x$ \\
\hline Low adherence & & $x$ \\
\hline Poor inhaler technique & & $x$ \\
\hline Active and past smoking & & $x$ \\
\hline Passive smoking & $x$ & \\
\hline
\end{tabular}

As for gender-related risk, different authors demonstrated an association with poor asthma control and both female and male gender (mild and severe exacerbations for female gender and higher SABA usage for males). ACQ-7, Asthma control questionnaire; SABA, Short acting $\beta 2$ agonists; mo, months. Data are from [3, 31-43] 
LABA/ICS controller therapy achieved well controlled asthma, $29 \%$ of patients remained poorly controlled. Moreover, severe asthma exacerbations, often triggered by viral infections, can occur even in patients with mild asthma that usually appears well controlled [46]. Although the role played by poor compliance to inhaled therapy and the little awareness of the disease severity among patients [40] has been largely recognized as a weak point in asthma control, some alternative mechanisms may in part justify this phenomenon.

\section{Why muscarinic antagonists as add-on therapy in asthma}

In the Symbicort Maintenance and Reliever Therapy (SMART) trial, chronic use of LABA has been related to a small but significant increase in risk of asthma-related deaths, especially among African Americans [47], rising the attention of the American Food and Drug Administration (FDA) on the possible role of a step-down approach of LABA in patients treated with LABA/ICS fixed dose combination (FDC), especially in asthmatic children [48-51]. Asthma control, exacerbations [52] and inflammation can worsen adding LABA to ICS [53]. It has been hypothesized that in asthma, long term use of LABA not associated with ICSs, is accompanied by down regulation of $\beta 2$ adrenoreceptors and thus by tachyphylaxis [54], with a loss of bronchoprotection $[55,56]$ and a reduction in responsiveness to reliever therapy with salbutamol $[57,58]$. A genetic-based subsensitivity of response to LABA/ICS FDC treatment can also derive from the Arg16/Arg16 $\beta 2$-receptor polymorphism, with an increased airway hyperresponsiveness in affected subjects [59-61]. Moreover, the efficacy and potency of $\beta 2$-agonists is gradually reduced in presence of increasing concentrations of contractile stimuli, including $\mathrm{M}_{\mathrm{R}}$ agonists and histamine both in vitro [62, 63] and in vivo [64]. The effect can be ascribed to the cross-talk between $G_{q}$-coupled muscarinic $M_{3 R}$ or histamine $H_{1}$ receptors and $G_{s}$ coupled $\beta 2$-adrenoceptors [65-67]. Another pathway inducing $\beta 2$-adrenoceptor desensitization can be mediated by $\beta 2$-agonists involving phosphorylation and activation of G-protein-coupled receptor kinase 2 [68]. The down regulation and uncoupling of pre-junctional $\beta 2$-adrenoreceptors secondary to prolonged LABA stimulation can increase cholinergic transmission [54], which acts via $M_{3 R}$ and protein-kinase $C$ phosphorylation. The administration of long acting muscarinic antagonists (LAMA) can thus counteract both the augmented cholinergic transmission and protect against LABA induced sub-sensitivity [69].

In this view, the application of antimuscarinic drugs in asthma had to be expected but was initially largely underestimated [70]; in fact, although they proved to be efficacious both in asthma and COPD especially in the acute setting [71], until a few years ago LAMA and short acting muscarinic antagonists (SAMA) were not part of the long term treatment strategy of international guidelines. This might be attributed to inconsistent results previously reported with SAMA (atropine and ipratropium) [72] that proved to be less effective in terms of acute bronchodilation when compared to salbutamol [72], which could be secondary to the lower drug doses [23] or, more probably, to the poor receptor selectivity of atropine and ipratropium. In fact, both anticholinergic molecules are not selective for $M_{3 R}$. An unselective blockade of $\mathrm{M}_{2 \mathrm{R}}$, which usually acts as a pre-synaptic auto-receptor for the blockade of further release of ACh from nerves to SM cells, can overcome the $M_{3 R}$ antagonism and thus favor bronchoconstriction [23, 73]. The rationale for the combination of LABA and LAMA in the maintenance therapy in asthma is also favoured by the interaction between $M_{R}$ and $\beta 2$-adrenoceptors in the airways [74]. In fact, administration of formoterol has been demonstrated to induce an upregulation of $\mathrm{M}_{3 \mathrm{R}}$ [75]. The augmented $\mathrm{ACh}$ release secondary to uncoupling of $\beta 2$-adrenoceptors during prolonged exposure to LABA might be prevented by administration of LAMA, which can also prevent LABA induced sub-sensitivity [54]. The cross-talk between adrenergic and cholinergic receptors might also justify a synergistic action of concomitant administration of LAMA and LABA/ICS therapy, by which LAMA may protect against adverse molecular effects secondary to long exposure to LABA [54].

\section{Tiotropium bromide}

The anticholinergic alkaloids contained in Atropa belladonna, Datura stramonium and Hyosciamus niger plants have been used as popular remedies to alleviate respiratory symptoms since ancient Egyptians times and the Middle Ages, when in Europe the deadly nightshade was used [76]. In the $19^{\text {th }}$ century atropine, a racemate of hyoscyamine [77], was isolated from nightshade, and became the progenitor of the modern anticholinergic compounds such as ipratropium. Since the '70s there was a renewed interest in anticholinergics as alternative options for the treatment of obstructive diseases, but ipratropium bromide, although demonstrated good clinical efficacy during acute asthma exacerbations [78], had a short duration of action and less bronchodilating effects compared with inhaled $\beta 2$-agonists [78]. In the '90s tiotropium bromide was developed [79]. Tiotropium bromide is a synthetic quaternary ammonium anticholinergic agent derived from ipratropium bromide [80] (molecular formula $\mathrm{C}_{19} \mathrm{H}_{22} \mathrm{BrNO}_{4} \mathrm{~S}_{2}$ [81]). Tiotropium demonstrated a high functional selectivity for specific $M_{R}$, with a long duration of action, being approximately 10 -fold more potent than 
ipratropium in binding $M_{R}$ in vitro and in vivo studies [82]. Kinetic studies showed that tiotropium had a high selectivity for $M_{1 R}$ and $M_{3 R}$ and dissociated 100 times slower than ipratropium from $\mathrm{M}_{1 \mathrm{R}}(14.6 \mathrm{~h}$ vs $0.11 \mathrm{~h})$ and $\mathrm{M}_{3 \mathrm{R}}(34.7 \mathrm{~h}$ vs $0.26 \mathrm{~h})$ [83]. At the same time it had dissociation time from $M_{2 R} 10$ times faster than from $M_{3 R}$, making it a selective functional antagonists of $M_{3 R}$ [79]. Further labeling and functional in vitro studies on human lungs confirmed its selectivity over $M_{2 R}$ [83]. Tiotropium is poorly absorbed from the gastro-intestinal tract and has very low systemic bioavailability [84]. After a single dose inhalation, peak plasma levels are reached after a maximum of $5 \mathrm{~min}$, with a subsequent rapid decline in $1 \mathrm{~h}$ to very low levels (in the $2 \mathrm{pg} / \mathrm{mL}$ range) [85]. Tiotropium is than eliminated with a terminal half-life of 5 to 6 days, in a dose-dependent manner [85]. In vitro functional studies demonstrated that, although with a slower onset of action compared with ipratropium, the offset of tiotropium is very long compared with atropine, with a half-life of $300 \mathrm{~min}$. These results justify the prolonged inhibitory effect of tiotropium in pharmacological in vivo studies. In asthmatic patients treated with tiotropium in doses from 10 to $80 \mu \mathrm{g}$, it demonstrated a protection against methacholine challenge for up to $48 \mathrm{~h}$ [86]; a prolonged and rapid onset of protection against methacholine challenge in patients with moderate airway hyper-responsiveness was later confirmed by Terzano and colleagues [87]. Analysis of pooled data from phase II and phase III RCTs in patients with asthma exposed to tiotropium delivered via Respimat $^{\ominus}$ shows that tiotropium is rapidly absorbed rapidly, with maximum plasma concentrations $5 \mathrm{~min}$ post-inhalation. Compared with COPD patients, the peak plasma concentration in patients with asthma was approximately 52\%, with no difference in exposure comparing the once daily and twice daily administration regimens. Age, allergic status, race, geographical region and smoking history did not appeared to influence the systemic exposure to tiotropium in patients with asthma [88]. In the numerous randomized clinical trials conducted in COPD [89], tiotropium showed an excellent and sustained bronchodilator effect [90], with proved efficacy in the reduction of static and dynamic volumes [91], in the reduction of the incidence of acute exacerbations [90], in the improvement of quality of life and symptoms [90], together with a good safety profile [91].

Approved for the long-term treatment of COPD since 2002 (2004 in the United States), tiotropium has been initially delivered via dry powder inhaler at the dosage of $18 \mu \mathrm{g} \mathrm{qd}$; since 2014, tiotropium has been delivered also via Respimat ${ }^{\oplus}$ SoftMist $^{\mathrm{Tm}}$ inhaler technology, with lowered dosages (5 $\mu \mathrm{g}$ once daily). Following positive large efficacy and safety trials in asthma, in 2014 the European Medicines Agency has extended the indication of tiotropium Respimat ${ }^{\ominus}$ at a dose of $2.5 \mu \mathrm{g}$ once daily (delivered in two inhalation of $1.25 \mu \mathrm{g}$ each) to patients with asthma, which was also approved in more than 50 countries, including Japan. In September 2015 the Food and Drug Administration confirmed the same indication; the latter being extended for patients aged 6 and older since $16^{\text {th }}$ February 2017.

\section{Tiotropium non-bronchodilator effects}

The immunopathologic response in asthma involves different inflammatory pathways and cells, mainly eosinophils, T-lymphocytes and macrophages which have a different role and are differently distributed in atopic and non atopic asthma $[92,93]$. The inflammatory response is not limited to the migration of inflammatory cells in the epithelium of the airways, but is also characterized by the modulation and activity of the epithelial barrier per se, with the involvement of fibroblasts and smooth muscle cells [94]. As the majority of the involved cells express muscarinic receptors, the role of the neuronal and non-neuronal cholinergic system and thus of LAMA administration can go far beyond the modulation of the bronchomotor tone, enhancing the anti-inflammatory and bronchodilator effects of LABA [95]. We present here a brief overview of the evidences of tiotropium ancillary effects in vivo and in vitro.

\section{Airway inflammation}

Allergen inhalation, cigarette smoke and exogenous stresses like methacholine induce inflammatory $\mathrm{M}_{3 \mathrm{R}}-$ mediated influx of eosinophils and neutrophils in the airways and are responsible for the production of numerous inflammatory mediator such as IL-8 and IL-6 [96]. However, the role of $\mathrm{ACh}$ in remodeling processes seems to be independent of the allergic inflammatory response and might be driven directly by bronchoconstriction, as demonstrated by the allergen-induced inflammation in knockout $M_{3 R}$ models [16]. Eosinophils are responsible for $M_{2 R}$ dysfunction in the lungs [16], while $\mathrm{ACh}$ is known to mediate the production of leukotriene-B4 (LTB4) and thus to lead neutrophil recruitment [97]. In animal models of allergic asthma, the protective effect of Tiotropium against airway hyperresponsiveness and airway inflammation was shown to be paralleled by a reduction in the eosinophil deposition in the airways $[23,98]$. The authors speculate that in this case Tiotropium acted through non conventional pathways, non-neuronal ACh release from macrophages and epithelial cells or acting directly on $M_{3 R}$ present on eosinophils, although the existence of the latter is to be confirmed yet. A suppressive activity of tiotropium on the production of macrophages-derived chemotactic mediators has been previously described mostly in COPD models. In vivo [97] and in vitro [99] studies have demonstrated a reduction in LTB4-mediated inflammation 
promoted by tiotropium; a reduction in neutrophilicmediated inflammation acting on the concentration of TNF- $\alpha$, IL- 6 and macrophage inflammatory proteins was also described in smoke induced neutrophilia [100] and in lipopolysaccharide-induced neutrophilia in a guinea pig model of COPD [101]. Although leukotriene-E4 inflammation represents a useful biomarker both for asthma control and treatment management, to date, studies addressing the potential role of tiotropium in the modulation of leukotriene-E4-induced inflammation in asthma are lacking. In a rhinovirus infection model of human tracheal cells, Turner and colleagues showed that tiotropium was able to reduce the viral RNA and cytokine levels in the supernatant fluid, reducing IL-6, IL- 8 and IL- $1 \beta$ levels [102]. Eosinophilic recruitment was affected also by a concomitant administration of tiotropium and budesonide or ciclesonide in animal models of asthma [103, 104]. Recent evidences in guinea pig models of asthma demonstrated a synergistic action between olodaterol and tiotropium when administered together; in fact, tiotropium supported and enhanced the protection against allergen-induced hyper-responsiveness, fully inhibiting the early and late asthmatic reaction [105]. The latter mechanism may be explained by the evidence that during charbacol induced inflammation of human fibroblasts, tiotropium seem to sustain olodaterol in restoring c-AMP levels in airway fibroblasts, cooperating to decrease the inflammatory response [93].

\section{Airway remodeling}

Chronic inflammation in asthma drives the pathological structural remodeling of the airways. $M_{3 R}$ mediate airway smooth muscle thickening and extracellular matrix deposition [17]. Previous experiments with fibroblasts from patients with COPD and active smokers demonstrated an increased expression of ChAT, $M_{1 R}$ and $M_{3 R}$ compared with fibroblasts from healthy controls, associated with an increased proliferation following Ach administration [106], a phenomenon down regulated by tiotropium and mediated by $M_{R}$, extracellular signalregulated kinase (ERK) 1/2 and nuclear factor (NF) kap$\mathrm{paB}$ [106]. In cultured fibroblasts and myofibroblasts, tiotropium was shown to inhibit ACh-induced proliferation in a concentration-dependent fashion [107] and to inhibit the production of metallo-proteinases-2 (MMP-2) while sparing tissue inhibitors of MMP-1 and MMP-2 [108, 109]. Tiotropium also showed an anti-remodeling and anti-hypertrophy effect on SM in a guinea pig asthma model [26]. In mice chronic asthma models tiotropium significantly decreased smooth muscle thickening and peribronchial collagen deposition [69], with a reduction of Th2-mediated cytokines such as Il4, IL5 and IL13, TGF- $\beta$ $[69,110]$. The association of tiotropium and budesonide or ciclesonide demonstrated to have inhibitory effects on allergen-induced inflammation and remodeling in vivo, although not in acute conditions [103, 104].

\section{Mucus production}

An increased mucus production is associated with lower quality of life, less disease control and more exacerbations, especially in smoker patients with asthma [111]. In healthy airways, MUC5AC is the most common mucin gene normally produced, but its expression is markedly increased in asthma and is mediated by $M_{3 R}$ which induce mucus production in goblet cells [112]. Selective $M_{3 R}$ with tiotropium showed an inhibition of neutrophil elastase-induce goblet cell metaplasia and neutrophil-elastase induced MUC5AC production [113]. Concomitant administration of tiotropium and inhaled steroids like budesonide [103] and dexamethasone [98] showed to reduce allergen-induced mucus gland hypertrophy and mucus hyper secretion in mice models of allergic asthma. Although having an effect on mucus production, tiotropium was not demonstrated to alter the rheological properties of mucus. The reported reduction of mucociliary clearance induced by the inhalation of old antimuscarinic drugs and tertiary ammonium compounds such as atropine was not reported after inhalation of ipratropium or tiotropium [16].

\section{Cough reflex}

Although the number of studies investigating the modulation of the cough reflex secondary to administration of antimuscarinic compounds is raising, the majority of them has been conducted in the 90's and all showed a reduction in cough threshold with administration of ipratropium [114-118]. However, the disease models used, the stimuli (mechanical, chemical) and the scale employed to evaluate the cough response differ widely [119] and thus the interpretation of the results appears difficult. The evidences that studied the effects of tiotropium are limited and mostly in animal models. In subjects with upper viral respiratory tract infection tiotropium after the first dose and after 7 days, with no correlation with changes in pulmonary function, suggesting mechanisms other than the modulation of the bronchomotor tone [120]. Birrell and colleagues [121] showed that tiotropium, but not glycopyrronium, was able to modulate the cough reflex through the transient-potential vanilloid receptor type-1 (TRPV1) with mechanisms not related to its anticholinergic activity, but rather interacting with another binding site on the channel or by acting indirectly as a modulator of the TRPV1 channel [121]. Further insight was given by Mutolo and coworkers that suggested that the down-regulation of cough promoted by tiotropium implied also the involvement of acid-sensing ion channels and mechanoreceptors [122]. 


\section{Dose finding \\ Children (6-11 years)}

A summary of phase II trials that investigated dose finding and safety of tiotropium in patients with uncontrolled asthma is reported in Table 2.

Three different tiotropium Respimat ${ }^{\oplus}$ evening doses (1.25 $\mathrm{gg}, 2.5 \mu \mathrm{g}$ and $5 \mu \mathrm{g}$ ) were tested in a phase II double-blind, placebo-controlled dose-ranging study in children with symptomatic asthma despite a maintenance therapy with medium-dose ICS with or without an antileukotriene (LTRA). Patients' mean (standard deviation, SD) reversibility at screening was of $370 \mathrm{~mL}$ (171). After 4 weeks of treatment, the peak $\mathrm{FEV}_{1}$ in the first $3 \mathrm{~h}(0-3 \mathrm{~h})$ post-dose period (primary endpoint) was improved by $87 \mathrm{~mL}(p=0.0002), 104 \mathrm{~mL}(p<0.0001)$ and $75 \mathrm{~mL}(p=0.0011)$, for $5 \mu \mathrm{g}, 2.5 \mu \mathrm{g}$ and $1.25 \mu \mathrm{g}$ respectively compared with placebo, with no statistical difference between doses. Similar significant improvements and no dose-dependent response were observed also for the mean trough $\mathrm{FEV}_{1}$ and the $\mathrm{FEV}_{1}$ area under the curve (AUC) between 0 and $3 \mathrm{~h}$ post-dose $(0-3 \mathrm{~h})$. All dosages improved the morning expiratory flow (PEF) compared to placebo, while the improvement in the evening PEF was limited to the highest dosage. Although not different compared to placebo, asthma control and quality of life were similarly improved, with a comparable and low rate of adverse events (AEs) [123].

\section{Adolescents (12-17 years)}

A randomized, double-blind, placebo-controlled, incomplete crossover study evaluated once-daily tiotropium $5 \mu \mathrm{g}$, $2.5 \mu \mathrm{g}$ and $1.25 \mu \mathrm{g}$ delivered via Respimat ${ }^{\bullet}$ versus placebo in three 4-week treatment periods; primary efficacy end point was change in peak $\mathrm{FEV}_{1}(0-3 \mathrm{~h})$. A significant improvement compared to placebo was found only for tiotropium $5 \mu \mathrm{g}(113 \mathrm{~mL}, p=0.0043)$. Again, the largest and only significant improvement compared to placebo for trough $\mathrm{FEV}_{1}$ was found for tiotropium $5 \mu \mathrm{g}$ (adjusted mean: $151 \mathrm{~mL} ; p<0.0001)$. A slightly more frequent occurrence of AEs compared to other dosages and placebo was present in patients treated with tiotropium $5 \mu \mathrm{g}$, while serious AEs ( 4 in total, 1 in the tiotropium $5 \mu$ group) were not considered related to the study treatment [124].

\section{Adults}

Tiotropium $5 \mu \mathrm{g}$ was demonstrated to be non-inferior to the dosage of $10 \mu \mathrm{g}$ and superior to placebo in terms of lung function outcomes in a study involving patients with uncontrolled severe asthma despite treatment with high dose ICS/LABA [125]. The higher dose of tiotropium, however, was associated with a higher rate of dry mouth occurrence [125].

The pharmacokinetic profile of two regimens of inhaled tiotropium, $2.5 \mu \mathrm{g}$ twice daily (TD) and $5 \mu \mathrm{g}$ once daily (OD), was tested in a phase II randomized controlled two way crossed over trial involving asthmatic patients in maintenance therapy with budesonide 400$800 \mu \mathrm{g}$ or equivalent [126]. The geometric mean of predose plasma concentrations of tiotropium at steady state ranged between $1.43 \mathrm{pg} / \mathrm{mL}(5 \mu \mathrm{g}$ OD) and $1.59 \mathrm{pg} / \mathrm{mL}$ (2.5 $\mu \mathrm{g}$ TD) [126], while the cumulative urinary excretion over $24 \mathrm{~h}$ was similar for both dosing regimens [126]. Accordingly, functional outcomes from Beeh et al. [126] and Timmer et al. [127] demonstrated no difference in $\mathrm{FEV}_{1} \mathrm{AUC}(0-24)$ for tiotropium $5 \mu \mathrm{g}$ OD an $\mathrm{d} 2.5 \mu \mathrm{g}$ $\mathrm{TD}$, while both dose regimens lead to a significant improvement compared to placebo [126, 127].

Efficacy and safety of three doses (namely $1.25 \mu \mathrm{g}$ to $2.5 \mu \mathrm{g}$ and $5 \mu \mathrm{g}$ ) of once-daily tiotropium Respimat ${ }^{\circ}$ were tested in a phase II, randomized, double-blind, placebo controlled, crossover study conducted in a population of moderate asthma patients treated with stable medium-dose ICS (400-800 $\mu \mathrm{g}$ budesonide or equivalent), alone or in a fixed-dose combination with a LABA. Lung function measured as peak $\mathrm{FEV}_{1}(0-3 \mathrm{~h})$ improved for all doses of tiotropium $\operatorname{Respimat}^{\oplus}(p<0.0001$ for all doses) with a largest mean difference from placebo observed for tiotropium $5 \mu \mathrm{g}(188 \mathrm{~mL}, 95 \%$ confidence interval, CI: 140, 236) [128].

\section{Safety}

Tiotropium long term safety as a primary outcome in asthma patients was specifically evaluated in a 52-weeks randomized controlled study in which tiotropium $5 \mu \mathrm{g}$, $2.5 \mu \mathrm{g}$ and placebo were administered in symptomatic Japanese patients as add-on therapy to ICS/LABA. The most common AEs reported were nasopharyngitis (48.2\%, 44.7\%, 42.1\%), asthma (28.9\%, 29.8\%, 38.6\%), decreased PEF $(15.8 \%, 7.9 \%, 21.1 \%)$, bronchitis (9.6\%, $13.2 \%, 7.0 \%)$, pharyngitis $(7.9 \%, 13.2 \%, 3.5 \%)$ and gastroenteritis $(10.5 \%, 3.5 \%, 5.3 \%)$ for $5 \mu \mathrm{g}, 2.5 \mu \mathrm{g}$ and placebo respectively. The rate of serious adverse effects was slow and not different between the study groups [129]. In the majority of phase II and III trials that evaluated tiotropium in asthma, patients with narrow angle glaucoma and symptomatic prostatic hypertrophy were excluded; nonetheless, considering the importance of such comorbidities in late onset asthma, the administration of tiotropium was not related to an increased frequency of AEs involving the eye, reproductive and urinary tract apparatuses. In the study conducted by Ohta et al. [129], the frequency of AEs related to eye disorders was usually very low, and lower in the tiotropium treated groups compared to placebo (5.3 and 6.1 vs $8.8 \%$ for patients treated with tiotropium $5 \mu \mathrm{g}, 2.5 \mu \mathrm{g}$ and placebo) [129]. In the same trial, cystitis was reported respectively by 4.4\% (tiotropium $5 \mu \mathrm{g}$ ), 2.6\% (tiotropium $2.5 \mu \mathrm{g}$ ) and $1.8 \%$ (placebo) of patients. A recent pooled analysis of 


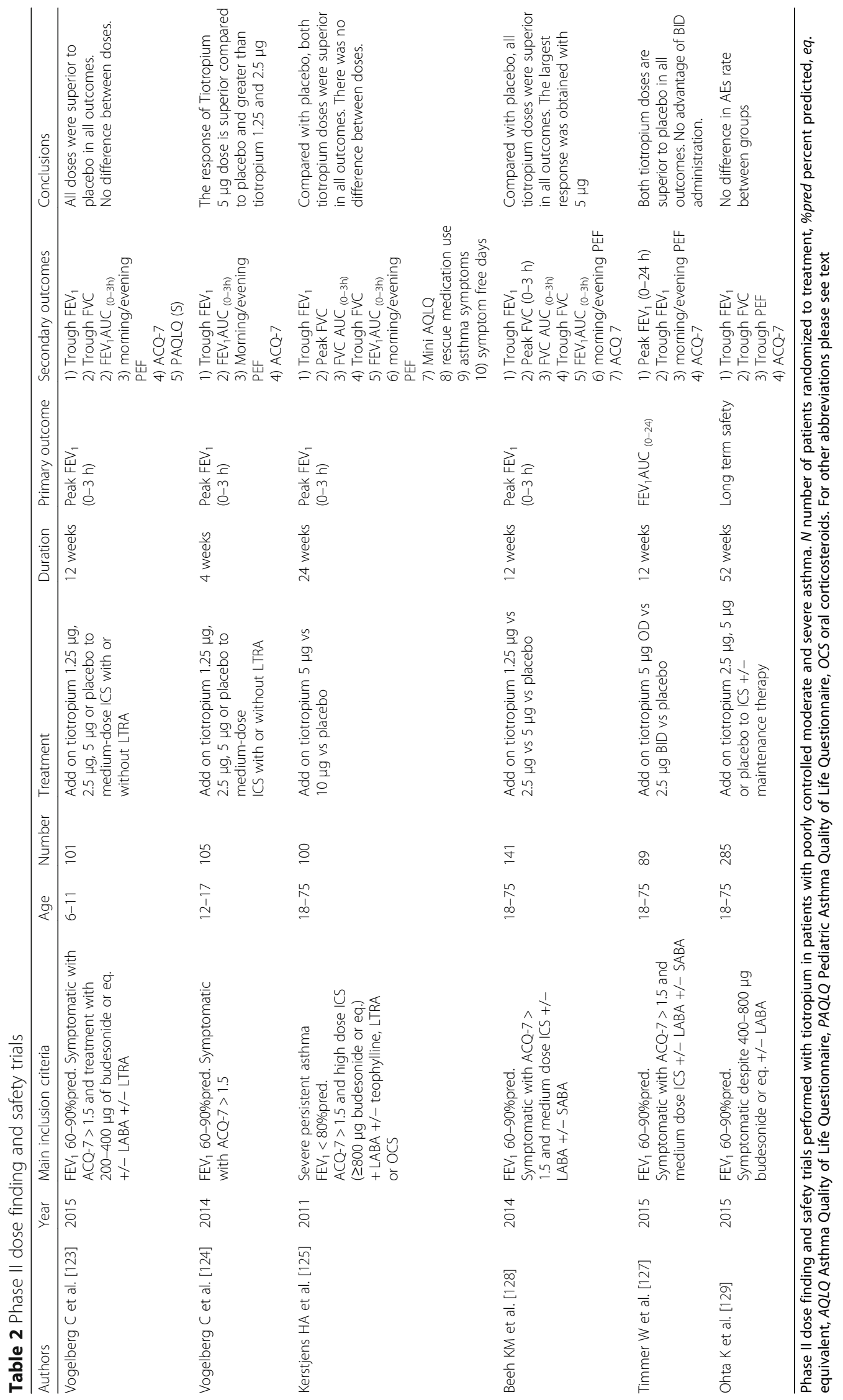


randomized, double blind parallel group phase II and III trials [130] investigated the safety profile of tiotropium $5 \mu \mathrm{g}$ and $2.5 \mu \mathrm{g}$, compared to placebo. Out of 3,474 patients analyzed, 2,157 received tiotropium. The overall percentage of patients reporting AEs was not different between groups, being $60.8 \%$ vs $62.5 \%$ for tiotropium $5 \mu \mathrm{g}$ and placebo $5 \mu \mathrm{g}$ and $57.1 \%$ vs 55.1 for tiotropium $2.5 \mu \mathrm{g}$ and placebo $2.5 \mu \mathrm{g}$. The most common AEs were represented by a reduction in PEF and nasopharyngitis. Adverse cardiac events were comparable between active treatments and placebo. AEs typically associated with use of LAMAs such as dry mouth was very low, ranging from $0.4 \%$ for tiotropium $2.5 \mu \mathrm{g}$ to $1.0 \%$ for tiotropium $5 \mu \mathrm{g}$. Serious AEs were similar between groups, albeit slightly higher for $5 \mu \mathrm{g}$ dose compared to $2.5 \mu \mathrm{g}$ (4.0\% vs $2.0 \%$, respectively) [130].

\section{Efficacy}

Following proof of concept studies, the efficacy and safety of tiotropium delivered via Respimat ${ }^{\circ}$ was investigated in a large scale clinical trial program (the UniTinA-asthma ${ }^{\circ}$ ) and in many independent studies, which included children, adolescents and adult patients. We summarized the main findings of the RCTs published so far dividing them by patients' age (Table 3 ). If not differently stated, all tiotropium doses are meant to be delivered by Respimat ${ }^{\circ}$ SofMist $^{\text {tw }}$ inhaler.

\section{Children and adolescents}

The efficacy of tiotropium was recently evaluated in patients $<18$ years old in four large, randomized double blind placebo controlled studies. A phase III, parallel-group 52 weeks RCT compared tiotropium $5 \mu \mathrm{g}$ (administered by 2 inhalations of $2.5 \mu \mathrm{g}$ ), tiotropium $2.5 \mu \mathrm{g}$ and placebo Respimat $^{\circ}$ given in the evening in adolescent patients with moderate symptomatic asthma. Symptomatic asthma was defined as an ACQ-7 mean score of at least 1.5. Patients had to be on maintenance therapy with ICSs, which was permitted during the study, with or without a LABA or a LTRA. Peak $\mathrm{FEV}_{1}(0-3 \mathrm{~h})$ after 24 weeks was the primary outcome. 376 patients completed the study. Peak $\mathrm{FEV}_{1}$ $(0-3 \mathrm{~h})$ was significantly and similarly improved for both tiotropium doses $(174 \mathrm{~mL}$ [95\% CI, 76-272 mL] for tiotropium $5 \mu \mathrm{g}$ and $134 \mathrm{~mL}$ [95\% CI,34-234 mL] for tiotropium $2.5 \mu \mathrm{g}$ ) compared with placebo. A rapid improvement of the forced expiratory flow (FEF) between $25 \%$ and $75 \%$ of $\mathrm{FVC}\left(\mathrm{FEF}_{25-75}\right)$ compared with placebo was also present beginning from $10 \mathrm{~min}$ post-dose for tiotropium $5 \mu \mathrm{g}$ and $1 \mathrm{~h}$ post dose with the $2.5 \mu \mathrm{g}$ dose. Trough FEV was significantly improved compared to placebo only for tiotropium $5 \mu \mathrm{g}$ : adjusted mean (standard error) $400 \mathrm{~mL}$ (41), $+117 \mathrm{~mL}$ (54) vs placebo, $p=0.03$ [131]. The same outcomes have been investigated by Hamelmann and coworkers [132] in adolescent patients with severe symptomatic asthma (ACQ-7 mean score of 21.5 ) despite medium to high doses of ICS (from $400 \mu \mathrm{g}$ to $1600 \mu \mathrm{g}$ of budesonide or equivalent in patients aged 15-17 and $>400 \mu \mathrm{g}$ in those aged $12-14$ years) and one or more controller therapies (LABA and/or LTRA). Peak $\mathrm{FEV}_{1}(0-3 \mathrm{~h})$ compared with placebo was significantly improved only with tiotropium $2.5 \mu \mathrm{g}(111 \mathrm{~mL}$; $p=0.046$ ), while all other outcomes, although showing a trend towards improvement, were not met [132]. The first and only phase III trial to assess the efficacy and safety of once-daily tiotropium add-on therapy in children with severe symptomatic asthma was published by Szefler SJ and colleagues [133]. Patients had to be symptomatic despite a maintenance therapy with medium ICS with two or more controller medications or high dose ICS with one or more controller medications and were randomized to receive tiotropium $5 \mu \mathrm{g}, 2.5 \mu \mathrm{g}$ or placebo for 12 weeks. Compared with placebo, only add-on tiotropium $5 \mu \mathrm{g}$ significantly improved peak $\mathrm{FEV}_{1}$ (0-3) (139 mL; 95\% CI, 75-203), and trough $\mathrm{FEV}_{1}$ (87 mL; 95\% CI, 19-154) with a good safety profile [133].

The efficacy of tiotropium $18 \mu \mathrm{g}$ administered by dry powder inhaler was tested in children and adolescents with moderate persistent asthma and compared with fluticasone $125 \mu \mathrm{g}$ via aerosol twice daily. After 12 weeks of treatment, the tiotropium/fluticasone group experienced significant improvements in $\mathrm{FEV}_{1}, \mathrm{FVC}$ and PEF and a reduced usage of SABA on demand therapy and night-time symptoms compared with fluticasone alone [134].

\section{Adults}

Initial proof of concept studies were conducted between late '90s and 2000 in adult asthmatic patients to prove tiotropium efficacy in protecting from methacholineinduced bronchoconstriction. O'Connor and colleagues [86], using doses of $10 \mu \mathrm{g}, 40 \mu \mathrm{g}$ and $80 \mu \mathrm{g}$, demonstrated that tiotropium was able to produce and maintain for $48 \mathrm{~h}$ a dose-dependent protection against methacholine challenge at $2 \mathrm{~h}$ [mean (standard error): 5.0 (1.1); 7.1 (0.5) and 7.9 (0.7) doubling doses], despite a mild increase in $\mathrm{FEV}_{1}$ that ranged between $5.5 \%$ and $11.1 \%$ from baseline [86]. Later on, Terzano and coworkers showed that tiotropium at a dose of $18 \mu \mathrm{g}$ delivered via HandiHaler ${ }^{\circ}$ had a protective effect against methacholine-induced bronchoconstriction in asthma patients with airway hyper-responsiveness. In fact, compared with placebo, patients treated with tiotropium did not reach the provocative dose causing a $20 \%$ decrease in basal $\mathrm{FEV}_{1}$ [87]. Another double blind, randomized, placebo controlled crossover study investigated the possibility to introduce tiotropium in order to step-down the ICS doses in severe asthma patients (mean $\mathrm{FEV}_{1} 51 \%$ predicted). While in patients treated with fluticasone $1000 \mu \mathrm{g}+\mathrm{LABA}$ lung function 
Radovanovic et al. Multidisciplinary Respiratory Medicine (2017) 12:12

Page 10 of 18

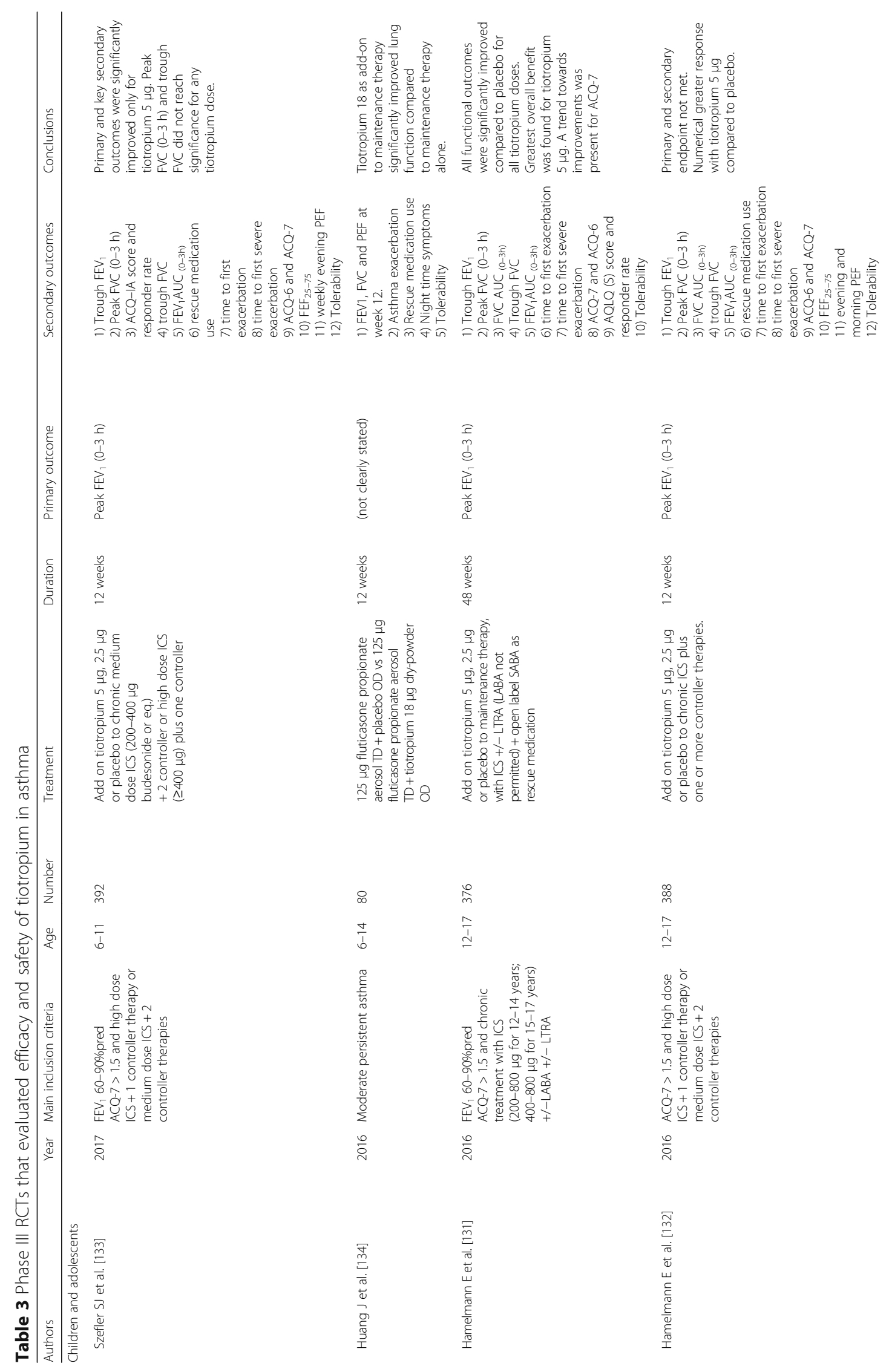


Radovanovic et al. Multidisciplinary Respiratory Medicine (2017) 12:12

Page 11 of 18

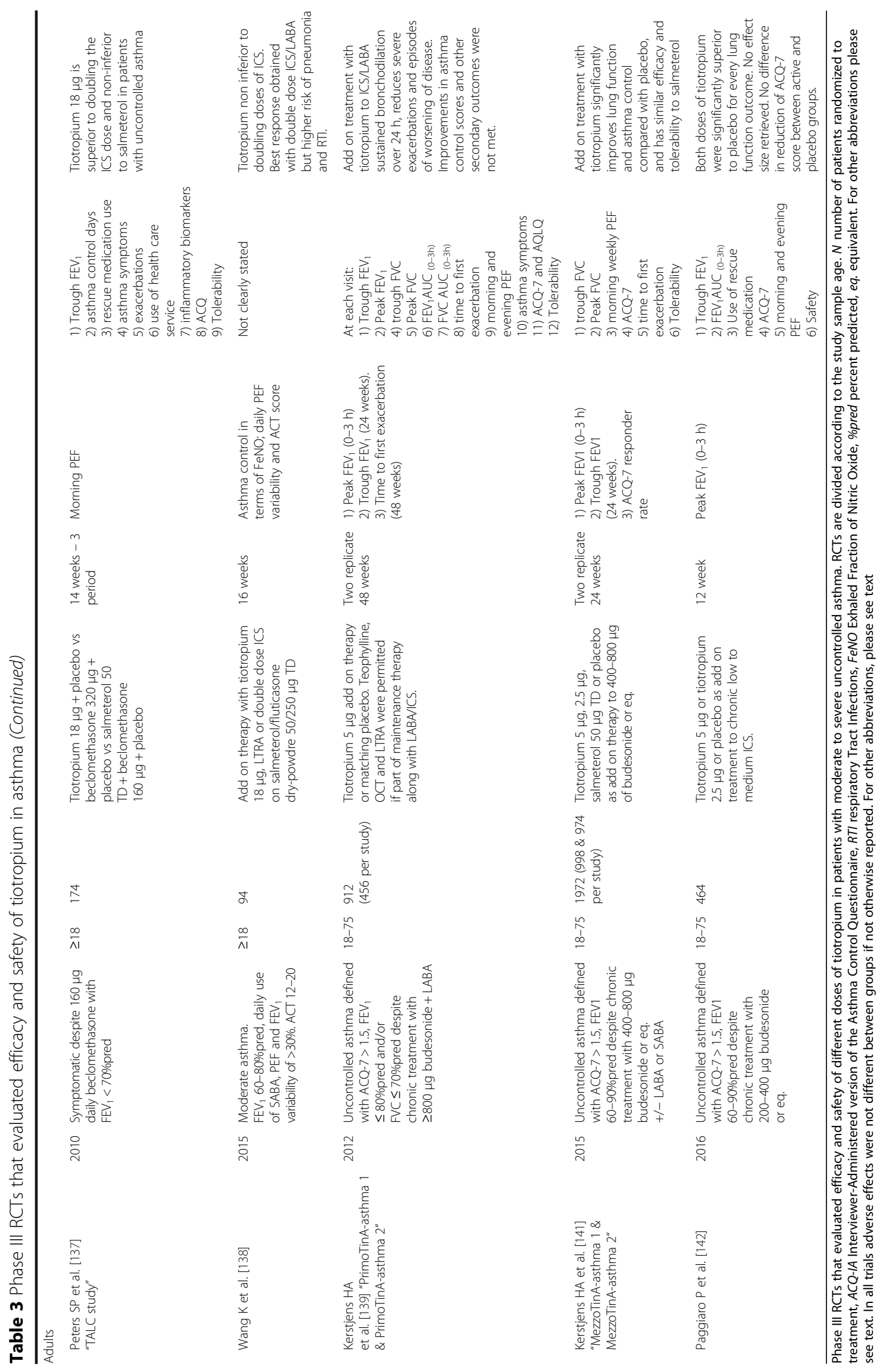


improvements were limited to PEF and airway resistances, only patients treated with tiotropium $18 \mu \mathrm{g}$, fluticasone $500 \mu \mathrm{g}+\mathrm{LABA}$ experienced also significant improvements in $\mathrm{FEV}_{1}(+170 \mathrm{~mL})$ and FVC $(+240 \mathrm{~mL})$ which were associated also to a reduction in exhaled nitric oxide by $2.86 \mathrm{ppb}$ compared to placebo [135]. Iwamoto and colleagues demonstrated also that improvements in airway obstruction following administration of tiotropium (dose not reported) in patients with severe asthma were positively correlated with neutrophil inflammation assessed by induced sputum, suggesting that tiotropium would be more effective in asthma patients with a non-eosinophilic phenotype [136].

The first large trial investigating the possibility to introduce tiotropium in the regular treatment in patients with uncontrolled asthma was the Tiotropium Bromide as an Alternative to Increased Inhaled Glucocorticoid in Patients Inadequately Controlled on a Lower Dose of Inhaled Corticosteroid (TALC) study [137]. In 210 patients with moderate to severe uncontrolled asthma with low doses of beclomethasone ( $80 \mu \mathrm{g}$ daily), the investigators evaluated the addition of tiotropium $18 \mu \mathrm{g}$ to beclomethasone $80 \mu \mathrm{g}$ daily as compared with doubling the dose of the ICS (primary superiority comparison) or with the addition of salmeterol to beclomethasone $80 \mu \mathrm{g}$ (secondary non-inferiority comparison). The addition of tiotropium to low-dose ICS resulted in significant improvements in all lung function and clinical outcomes compared to doubling the ICS dosage. Compared to the latter group, the association of tiotropium improved both morning and evening PEF were improved with tiotropium $(+25.8 \mathrm{l} / \mathrm{min}$; 95\% CI, 14.4-37.1; $p<0.001$ and $+35.3 \mathrm{l} / \mathrm{min}$; $95 \% \mathrm{CI}, 24.6-46.0 ; p<0.001$, respectively), the pre-dose $\mathrm{FEV}_{1}(+100 \mathrm{~mL}, p=0.004)$, the proportion of asthma-control days, score for daily symptoms, and the ACQ-7 (-0.18 points; $p=0.02)$. Moreover, tiotropium add-on therapy resulted to be non inferior to the LABA/ICS association in all outcomes [137]. Confirmatory results came from a singlecenter study in which treatment with tiotropium + LABA + low dose ICS was non inferior in functional outcomes and nitric oxide reduction to LABA + double dose ICS in patients with uncontrolled asthma [138].

Subsequently, two replicate, randomized, placebocontrolled 48-week period trials (PrimoTinA-asthma 1 and PrimoTinA-asthma 2) were designed to specifically assess if tiotropium $5 \mu \mathrm{g}$ add on therapy to high dose ICS + LABA compared to add-on placebo was effective in improving disease control both in terms of lung function [peak $\mathrm{FEV}_{1}(0-3 \mathrm{~h})$ and through $\mathrm{FEV}_{1}$ ] and of time to first exacerbation in patients poorly controlled with maintenance therapy [139]. Patients had to have a $\mathrm{FEV}_{1}<80 \%$ predicted and a history of at least 1 severe asthma exacerbation in the previous year. Change in peak $\mathrm{FEV}_{1}(0-3 \mathrm{~h})$ from baseline was significantly greater with tiotropium than with placebo in both trials (vs placebo, mean \pm SE: $86 \pm 34 \mathrm{~mL}$ and $154 \pm 32 \mathrm{~mL}$ ), and this was true also for the trough $\mathrm{FEV}_{1}$ (vs placebo: $88 \pm 31 \mathrm{~mL}$ and $111 \pm 30 \mathrm{~mL}$ ). Time to the first severe exacerbation was increased in patients treated with add-on tiotropium (282 days vs. 226 days), with an overall reduction of $21 \%$ in the risk of a severe exacerbation (hazard ratio: 0.79; $p=0.03$ ) [139]. The response to treatment with tiotropium was shown to be independent of baseline characteristics including gender, age, body mass index, disease duration, age at asthma onset, $\mathrm{FEV}_{1} \%$ predicted at screening and reversibility [140].

The non inferiority of tiotropium compared to LABA as add-on therapy to ICS in patients with moderate asthma was investigated in two 24-week, replicate, randomized, double-blind, placebo-controlled, parallel-group, active comparator trials (MezzoTinA-asthma 1 and MezzoTinA-asthma 2) [141]. These two parallel trials randomized a total of 2,103 patients to receive tiotropium $5 \mu \mathrm{g}$ OD, tiotropium $2.5 \mu \mathrm{g}$ OD, salmeterol $50 \mu \mathrm{g}$ BID or placebo on top of maintenance therapy with medium dose budesonide $(400-800 \mu \mathrm{g})$. Again, the two functional coprimary end-points were peak $\mathrm{FEV}_{1}(0-3 \mathrm{~h})$ and through $\mathrm{FEV}_{1}$ at the end of the 24-week treatment period, additionally, the study assessed the proportion of responders by means of the ACQ-7, i.e. patients that increased the ACQ-7 score more than 0.5. Pooled data of the 1,972 patients that completed the studies showed significant improvements for both doses of tiotropium and salmeterol compared to placebo in all functional outcomes. Compared to placebo, both doses of tiotropium and salmeterol significantly improved peak $\mathrm{FEV}_{1}(0-3 \mathrm{~h})$ and trough $\mathrm{FEV}_{1}$, although results were numerically higher for tiotropium $2.5 \mu \mathrm{g}$. There were more ACQ-7 responders in the tiotropium $5 \mu \mathrm{g}$ (OR 1.32; 95\% CI: 1.02-1.71; $P=0.035)$, $2.5 \mu \mathrm{g}(1.33$; 95\% CI: $1.03-1.72 ; P=0.031)$ and the salmeterol group (1.46, 95\% CI: $1.13-1.89 ; p=0.0039)$, compared to placebo. Although median time to first severe exacerbation could not be calculated because less than $50 \%$ of patients in each treatment group had one or more severe exacerbations, a statistically significant reduction in risk of first severe exacerbation was reported for tiotropium $2.5 \mu \mathrm{g}$ and of first asthma worsening for tiotropium $2.5 \mu \mathrm{g}$ and salmeterol [141]. A recent phase III RCT compared tiotropium $2.5 \mu \mathrm{g}$ and $5 \mu \mathrm{g}$ OD versus placebo as add-on therapy to maintenance treatment with ICS in patients with moderate symptomatic asthma with a $\mathrm{FEV}_{1}$ of 60 to $90 \%$ predicted. Data from 464 patients were analyzed. After 12 weeks of treatment, both dose regimens showed superiority over placebo in terms of through $\mathrm{FEV}_{1}$ and peak $\mathrm{FEV}_{1}(0-3 \mathrm{~h})$; however, numerically better results for peak $\mathrm{FEV}_{1}(0-3 \mathrm{~h})$ and $\mathrm{FEV}_{1 \mathrm{AUC}}(0-3 \mathrm{~h})$ were found for tiotropium $2.5 \mu \mathrm{g}$ compared to $5 \mu \mathrm{g}$ [adjusted 
mean (SE): $293 \mathrm{~mL}$ (26) vs $262 \mathrm{~mL}$ (26) and $198 \mathrm{~mL}$ (24) vs $174 \mathrm{~mL}$ (25), respectively]. The frequency of AEs was not different across the treatment regimens [142].

These large studies demonstrated the efficacy of tiotropium as add-on therapy both to moderate-to-high dose of ICS and to ICS/LABA maintenance therapy in terms of lung function, risk of exacerbation and disease worsening, goals that were achieved with a safety profile similar to LABA comparators and placebo. Further post hoc analyses of pooled data from MezzoTinA-asthma 1, MezzoTinAasthma 2, PrimoTinA-asthma 1 and PrimoTinA-asthma 2 suggested that the efficacy of tiotropium was independent of underlying allergic/eosinophilic inflammation and thus of the T-helper 2 asthma phenotype, as outcomes were reached in patients with a broad range of $\mathrm{IgE}$ and eosinophil values [143].

The Arg16/Arg16 $\beta 2$-adrenergic receptors polymorphism represents a common finding both in African Americans (20\%) and Caucasians (15\%) [59] and is associated with a blunted sensitivity to the maintenance asthma treatment with SABAs thus justifying a worse disease control with long term treatment with ICS/LABA FDC both in adults [144] and in children [145]. This assumption led to investigate the predictors of response to therapy by means of a pharmacogenetic approach. Sequencing of eleven different nucleotide polymorphisms was performed in 138 asthmatic not controlled with their maintenance therapy in which tiotropium $18 \mu \mathrm{g}$ was added once daily. The positive response to tiotropium in terms of lung function was found in 33\% of patients and was predicted by the Arg16Gly polymorphism [146]. When a cohort of asthmatic patients homozygous for the Arg16 $\beta 2$ adrenergic receptor polymorphism were prospectively studied, tiotropium demonstrated to be non inferior to salmeterol in improving the morning PEF (mean $\pm \mathrm{SD} ;-3.9 \pm 4.87 \mathrm{~L} / \mathrm{min}$ for tiotropium and $-3.2 \pm$ 4.64 L/min for salmeterol) [147]. Given the proportion of African-American patients with allelic variations associated with poor asthma control, a study specifically powered and designed to assess the risk of exacerbations in this particular population was set in 2011. The Blacks and Exacerbations on LABA vs Tiotropium (BELT study) [148] was a parallel-group, randomized pragmatic trial that enrolled black adults with asthma from primary care and specialty practices in the United States. Participants were enrolled if on step 3 or step 4 combination ICS and LABA therapy, and were randomized to receive a LABA (salmeterol or formoterol) or tiotropium in addition to their chronic dose of ICS. The primary outcome was time to asthma exacerbation, secondary outcomes included patient-reported outcomes, lung function ( $\mathrm{FEV}_{1}$ changes), rescue medication use and AEs. The investigators found no

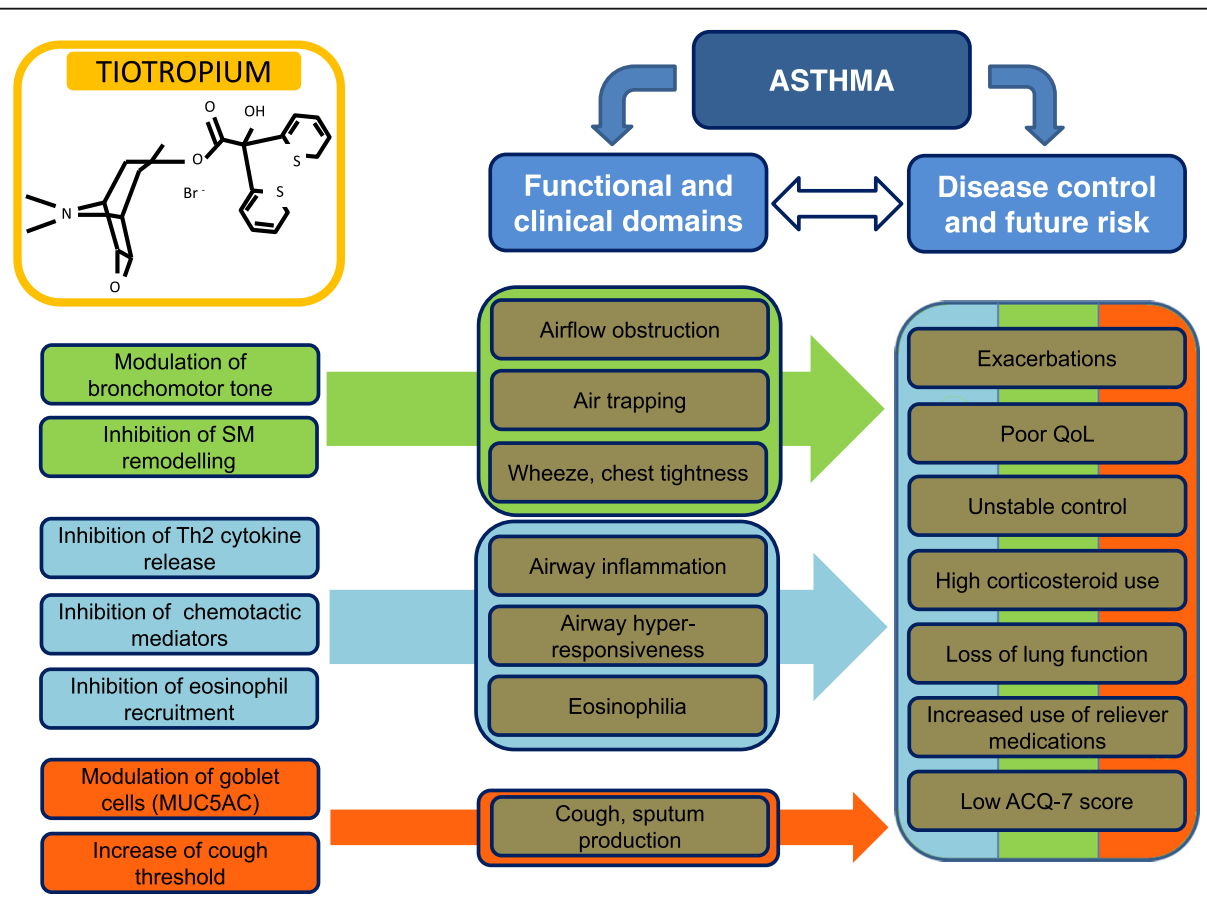

Fig. 1 Possible role of tiotropium bromide in the management of asthma. The colour code refers to the functional and clinical characteristics that tiotropium should be able to modify according to its pharmacological properties. If the effect on functional and clinical asthma domains is effected prevalently by specific tiotropium properties, the effect on asthma control and future risk might be modulated by the concomitant action of different characteristics taken together. Th2, T helper-2 lymphocytes; SM, smooth muscle cells; MUC5AC, mucin-5 subtype AC gene; QoL, Quality of Life; ACQ-7, Asthma Control Questionnaire 
difference between the two treatment regimens in terms of primary and secondary outcomes. Neither of the Arg16Gly $\beta 2$-adrenergic receptors alleles was associated with differences in the effects of tiotropium + ICS vs LABA + ICS [148].

Initial validations of these RCTs in real life settings can be found in two recent retrospective studies. An analysis of 64 patients with poor disease control despite treatment with high dose ICS/LABA showed that the introduction of tiotropium as add on therapy improved asthma control in $42.2 \%$ of cases, decreasing the number of emergency department visits and hospitalizations in $46.9 \%$ and $50.0 \%$ of cases, respectively [149]. A larger cohort involving 2,042 outpatients from United Kingdom compared the number of exacerbations (emergency visits, hospitalizations and oral corticosteroids use) and acute asthma events (antibiotic use for lower respiratory tract infections) in the year before and in the year following the prescription of tiotropium. Patients experienced an overall significant decrease in exacerbations and acute asthma events by $10 \%$ and $11 \%$; however, there was a significant increase in the as needed usage of SABA from a median (IQR) of $274(110-548)$ to 329 (110-603) $\mu \mathrm{g} /$ day [150].

\section{Conclusions}

Asthma control represents the main goal of numerous respiratory societies worldwide and a lot of energy has been spent so far trying to change quality of life of patients with uncontrolled asthma. Beside patient dependent factors, advances in maintenance therapy represent one of the cornerstones of risk management and disease control. Following its proven efficacy and safety in patients with COPD, a large body of evidence is now available for the use of tiotropium also in patients with poor controlled asthma. Large RCTs performed with patients with moderate to severe asthma have demonstrated its efficacy in improving lung function, decreasing risk of exacerbation and slowing the worsening of disease as add-on therapy, and its non inferiority compared to LABAs along the ICS maintenance treatment. In view of the ancillary and the synergistic effects provided by the cross-talk between $\beta 2$ and muscarinic receptors, tiotropium can represent a beneficial alternative in the therapeutic management of poor controlled asthma (Fig. 1). Tiotropium safety profile and the broad spectrum of efficacy demonstrated in different disease phenotypes allows its use also in the pediatric and allergic population. More studies in human models of asthma are needed to explore its invivo anti-inflammatory effects, its impact on lung volumes and airway resistances and thus its role as disease modifier in the natural history of asthma.

\section{Abbreviations}

95\%Cl: 95\% Confidence interval; ACh: Acetylcholine; ACQ-7: Asthma control questionnaire; AEs: Adverse events; AUC: Area under the curve; ChAT: Choline acetyl-transferase; COPD: Chronic obstructive pulmonary disease; FDC: Fixed dose combination; $\mathrm{FEV}_{1}$ : Forced expiratory volume in one second; $\mathrm{FEV}_{1}(\mathrm{O}-3 \mathrm{~h})$ : Peak forced expiratory volume in one second in the first $3 \mathrm{~h}$ post-administration; FVC: Forced vital capacity; ICS: Inhaled corticosteroids; IQR: Inter quartile range; LABA: Long acting $\beta 2$-agonists; LAMA: Long acting muscarinic antagonists; LTRA: Antileukotriene; MR: Muscarinic receptors; MUC5AC: Mucin-5 subtype AC gene; OD: Once daily; PEF: Peak expiratory flow; QoL: Quality of life; RCT: Randomized controlled trial; SABA: Short acting $\beta 2$-agonists;

SAMA: Short acting muscarinic antagonists; SD: Standard deviation; SE: Standard error; SM: Smooth muscle; TD: Twice daily; Th2: T lymphocytes type 2

\section{Acknowledgements}

None.

Funding

Not applicable.

Availability of data and materials

Not applicable.

Authors' contributions

$D R, P S, F B$ and MM equally participated in the review of the literature and in the drafting, editing and reviewing of the manuscript. All authors read and approved the final manuscript.

\section{Competing interests}

DR has not competing interest to declare. PS reports research grants from Chiesi Farmaceutici, Pfizer, AirLiquide and Almirall; personal fees for lectures and/or advisory boards from Chiesi Farmaceutici, AstraZeneca, Boehringer Ingelheim, Novartis, Menarini, Malesci/Guidotti, Mundipharma and Zambon. FB has received research grants from Boehringer Ingelheim, Chiesi, Zambon, and Pfizer, congress lecture fees from Boehringer Ingelheim, Guidotti-Malesci, Menarini, GSK, Chiesi, Pfizer and Novartis, and consultancy fees from AstraZeneca, Menarini, Mundipharma, Novartis, GSK, Teva and Pfizer. MM reports travel and congress participation reimbursements from Boehringer Ingelheim, Menarini, Vivisol and Astra Zeneca; personal fees for teaching in training course from Malesci/Guidotti. The authors report no other conflicts of interest in this work.

Consent for publication

Not applicable.

Ethics approval and consent to participate

Not applicable.

\section{Publisher's Note}

Springer Nature remains neutral with regard to jurisdictional claims in published maps and institutional affiliations.

\section{Author details}

${ }^{1}$ Department of Biomedical and Clinical Sciences (DIBIC), University of Milan, Pulmonary Unit, Ospedale L. Sacco, ASST Fatebenfratelli-Sacco, Milan, Italy. ${ }^{2}$ Department of Pathophysiology and Transplantation, University of Milan, Cardio-thoracic unit and Adult Cystic Fibrosis Center, Fondazione IRCCS Ca' Granda Ospedale Maggiore Policlinico, Milan, Italy.

Received: 18 March 2017 Accepted: 18 April 2017

Published online: 04 May 2017

\section{References}

1. Skloot GS, Busse PJ, Braman SS, Kovacs EJ, Dixon AE, Vaz Fragoso CA, et al. An official American Thoracic Society workshop report: evaluation and management of asthma in the elderly. Ann Am Thorac Soc. 2016;13(11): 2064-77.

2. World Health Organization (WHO). Facts on asthma. Fact sheet $n^{\circ} 307$ http://www.who.int/features/factfiles/asthma/asthma_facts/en/ 2013. Accessed 23 Apr 2017

3. Global strategy for asthma management and prevention in: Global Initiative for Asthma (GINA). 2017. Available from: http://ginasthma.org/2017-gina- 
report-global-strategy-for-asthma-management-and-prevention/. Accessed 20 Jan 2017.

4. National Asthma Education and Prevention Program. Third Expert Panel on the Diagnosis and Management of Asthma (EPR-3). U.S. Department of Health and Human services, National Heart, Lung and Blood Institute. 2007. https://www.nhlbi.nih.gov/files/docs/guidelines/asthsumm.pdf.

Accessed 15 Feb 2017

5. Agusta F, Battaglia S, Benfante A, Spatafora M, Scichilone N. Challenges in the pharmacological treatment of geriatric asthma. Expert Rev Clin Pharmacol. 2016:9(7):917-26.

6. Ventura MT, Scichilone N, Paganelli R, Minciullo PL, Patella V, Bonini M, et al. Allergic diseases in the elderly: biological characteristics and main immunological and non-immunological mechanisms. Clin Mol Allergy. 2017;15:2.

7. Sullivan PW, Ghushchyan VH, Campbell JD, Globe G, Bender B, Magid DJ. Measuring the cost of poor asthma control and exacerbations. J Asthma. 2017:54(1):24-31.

8. Yamauchi $Y$, Yasunaga $H$, Matsui $H$, Hasegawa W, Jo T, Takami $K$, et al. Comparison of in-hospital mortality in patients with COPD, asthma and asthma-COPD overlap exacerbations. Respirology. 2015;20(6):940-6.

9. Huang S, Vasquez M, Halonen M, Martinez FD, Guerra S. Asthma, airflow limitation, and mortality risk in the general population. Eur Respir J. 2015; 45(2):338-46.

10. Litonjua AA, Apter AJ, Weiss ST. Asthma: epidemiology. In: Grippi MA, Elias JA, Fishman JA, Kotoff RM, Pack Al, Senior RM, editors. Fishman's Pulmonary Diseases and Disorders. 5th Edn. New York: McGraw Hill Education; 2015. p. 687-700.

11. Kaur BP, Lahewala S, Arora S, Agnihotri K, Panaich SS, Secord E, et al. Asthma: hospitalization trends and predictors of in-hospital mortality and hospitalization costs in the USA (2001-2010). Int Arch Allergy Immunol. 2015;168(2):71-8.

12. Santus $P$, Radovanovic D. Prostaglandin D2 receptor antagonists in early development as potential therapeutic options for asthma. Expert Opin Investig Drugs. 2016;25(9):1083-92.

13. Sastre J, Fabbri LM, Price D, Wahn HU, Bousquet J, Fish JE, et al. Insights, attitudes, and perceptions about asthma and its treatment: a multinational survey of patients from Europe and Canada. World Allergy Organ J. 2016;9:13.

14. Canonica GW, Baena-Cagnani CE, Blaiss MS, Dahl R, Kaliner MA, Valovirta EJ, GAPP Survey Working Group. Unmet needs in asthma: global asthma physician and patient (GAPP) survey: global adult findings. Allergy. 2007; 62(6):668-74.

15. Bateman ED, Boushey HA, Bousquet J, Busse WW, Clark TJ, Pauwels RA, et al. Can guideline-defined asthma control be achieved? the gaining optimal asthma ControL study. Am J Respir Crit Care Med. 2004;170(8):836-44.

16. Cazzola M, Ora J, Rogliani P, Matera MG. Role of muscarinic antagonists in asthma therapy. Expert Rev Respir Med. 2017;11(3):239-53.

17. Matera G, Cazzola M. Muscarinic receptor antagonists in pharmacology and therapeutics of asthma and COPD. Handb Exp Pharmacol. 2016;237:41-62.

18. Rodger IW, Small RC. Pharmacology of airway smooth muscle in pharmacology of asthma. Handb Exp Pharmacol. 1991;98:107-41.

19. Racké K, Matthiesen S. The airway cholinergic system: physiology and pharmacology. Pulm Pharmacol Ther. 2004;17(4):181-98.

20. Price D, Fromer L, Kaplan A, van der Molen T, Román-Rodríguez M. Is there a rationale and role for long-acting anticholinergic bronchodilators in asthma? NPJ Prim Care Respir Med. 2014;24:14023.

21. Bateman ED, Rennard S, Barnes PJ, Dicpinigaitis PV, Gosens R, Gross NJ, et al. Alternative mechanisms for tiotropium. Pulm Pharmacol Ther. 2009;22(6):533-42.

22. Belmonte KE. Cholinergic pathways in the lungs and anticholinergic therapy for chronic obstructive pulmonary disease. Proc Am Thorac Soc. 2005;2(4): 297-304.

23. Buels KS, Jacoby DB, Fryer AD. Non-bronchodilating mechanisms of tiotropium prevent airway hyperreactivity in a guinea-pig model of allergic asthma. Br J Pharmacol. 2012;165(5):1501-14.

24. Pieper MP. The non-neuronal cholinergic system as novel drug target in the airways. Life Sci. 2012;91(21-22):1113-8.

25. Gosens R, Zaagsma J, Meurs H, Halayko AJ. Muscarinic receptor signaling in the pathophysiology of asthma and COPD. Respir Res. 2006;7:73.

26. Gosens R, Bos IS, Zaagsma J, Meurs H. Protective effects of tiotropium bromide in the progression of airway smooth muscle remodeling. Am J Respir Crit Care Med. 2005;171:1096-102.
27. Global strategy for asthma management and prevention in: Global Initiative for Asthma (GINA). 2015. Available from: www.ginasthma.org. Accessed 18 Feb 2017.

28. Bateman ED, Bousquet J, Busse WW, Clark TJ, Gul N, Gibbs M, et al. Stability of asthma control with regular treatment: an analysis of the gaining optimal asthma controL (GOAL) study. Allergy. 2008;63:932-8.

29. Reddel HK, Taylor DR, Bateman ED, Boulet LP, Boushey HA, Busse WW, et al. An official American Thoracic Society/European Respiratory Society statement: asthma control and exacerbations: standardizing endpoints for clinical asthma trials and clinical practice.

Am J Respir Crit Care Med. 2009;180(1):59-99.

30. Blasi F, Bettoncelli G, Canonica GW, Centanni S, Crimi N, DiMaria G, et al. The management of asthma in the phenotype and biomarker era: the proposal of a new diagnostic-therapeutic model. J Asthma. 2016;53(7):665-7.

31. Wu TJ, Chen BY, Lee YL, Hsiue TR, Wu CF, Guo YL. Different severity and severity predictors in early-onset and late-onset asthma: a Taiwanese population-based study. Respiration. 2015;90(5):384-92.

32. Papaioannou Al, Kostikas K, Bakakos P, Papaporfyriou A, Konstantellou E, Hillas $\mathrm{G}$, et al. Predictors of future exacerbation risk in patients with asthma. Postgrad Med. 2016;128(7):687-92.

33. Loymans RJ, Honkoop PJ, Termeer EH, Snoeck-Stroband JB, Assendelft WJ, Schermer TR, et al. Identifying patients at risk for severe exacerbations of asthma: development and external validation of a multivariable prediction model. Thorax. 2016;71(9):838-46.

34. Bateman ED, Buhl R, O'Byrne PM, Humbert M, Reddel HK, Sears MR, et al. Development and validation of a novel risk score for asthma exacerbations: the risk score for exacerbations. J Allergy Clin Immunol. 2015;135(6):1457-64.

35. Lee T, Kim J, Kim S, Kim K, Park Y, Kim Y, et al. Risk factors for asthma-related healthcare use: longitudinal analysis using the $\mathrm{NHI}$ claims database in a Korean asthma cohort. PLoS One. 2014;9(11):e112844.

36. Stephenson JJ, Quimbo RA, Gutierrez B. Subacute lack of asthma control as a predictor of subsequent acute asthma exacerbation in a managed care population. Am J Manag Care. 2010;16:108-14.

37. Sims EJ, Price D, Haughney J, Ryan D, Thomas M. Current control and future risk in asthma management. Allergy, Asthma Immunol Res. 2011; 3(4):217-25.

38. Braido F, Brusselle G, Guastalla D, Ingrassia E, Nicolini G, Price D, et al. Determinants and impact of suboptimal asthma control in Europe: the international cross-sectional and longitudinal assessment on asthma control (LIAISON) study. Respir Res. 2016;17(1):51.

39. Braido F. Failure in asthma control: reasons and consequences. Scientifica. 2013;2013:549252.

40. Price $D$, Fletcher $M$, van der Molen T. Asthma control and management in 8,000 european patients: the REcognise asthma and LInk to symptoms and experience (REALISE) survey. NPJ Prim Care Respir Med. 2014;24:14009.

41. Sasaki M, Yoshida K, Adachi Y, Furukawa M, Itazawa T, Odajima H, et al. Factors associated with asthma control in children: findings from a national Web-based survey. Pediatr Allergy Immunol. 2014;25(8):804-9.

42. Zomer-Kooijker K, Uiterwaal CS, Verschueren KJ, Maitland-vd Zee AH, Balemans WA, van Ewijk BE, et al. Respiratory tract infections and asthma control in children. Respir Med. 2014;108(10):1446-52.

43. Ginis T, Akcan FA, Capanoglu M, Toyran M, Ersu R, Kocabas CN, et al. The frequency of sleep-disordered breathing in children with asthma and its effects on asthma control. J Asthma. 2017. doi: 10.1080/02770903.2016. 1220012.

44. Melani AS, Bonavia M, Cilenti V, Cinti C, Lodi M, Martucci P, et al. Inhaler mishandling remains common in real life and is associated with reduced disease control. Respir Med. 2011;105:930-8.

45. Scichilone N, Benfante A, Bocchino M, Braido F, Paggiaro P, Papi A, et al. Which factors affect the choice of the inhaler in chronic obstructive respiratory diseases? Pulm Pharmacol Ther. 2015;31:63-7.

46. Patella V, Santus $P$, Puggioni F, Steinhilber $G$, Scichilone N. Is mild asthma in real life always in the green zone? Minerva Med. 2014;105 Suppl 2:1-6.

47. Nelson HS, Weiss ST, Bleecker ER, Yancey SW, Dorinsky PM, SMART Study Group. The salmeterol multicenter asthma research trial: a comparison of usual pharmacotherapy for asthma or usual pharmacotherapy plus salmeterol. Chest. 2006;129(1):15-26.

48. Currie GP, Lee DK, Lipworth BJ. Long-acting beta2-agonists in asthma: not so SMART? Drug Saf. 2006;29(8):647-56. 
49. Lipworth BJ. Long-acting beta2-adrenoceptor agonists: a smart choice for asthma? Trends Pharmacol Sci. 2007;28(6):257-62.

50. Drazen JM, O'Byrne PM. Risks of long-acting beta-agonists in achieving asthma control. N Engl J Med. 2009:360(16):1671-2.

51. Chowdhury BA, Dal Pan G. The FDA and safe use of long-acting beta-agonists in the treatment of asthma. N Engl J Med. 2010;362(13): 1169-71.

52. Gibson PG, Powell H, Ducharme FM. Differential effects of maintenance long-acting beta-agonist and inhaled corticosteroid on asthma control and asthma exacerbations. J Allergy Clin Immunol. 2007;119(2):344-50.

53. Green RH, Brightling CE, McKenna S, Hargadon B, Neale N, Parker D, et al. Comparison of asthma treatment given in addition to inhaled corticosteroids on airway inflammation and responsiveness. Eur Respir J. 2006;27(6):1144-51.

54. Lipworth BJ. Emerging role of long acting muscarinic antagonists for asthma. Br J Clin Pharmacol. 2014;77(1):55-62.

55. Lipworth B, Tan S, Devlin M, Aiken T, Baker R, Hendrick D. Effects of treatment with formoterol on bronchoprotection against methacholine. Am J Med. 1998;104(5):431-8.

56. Aziz I, Tan KS, Hall IP, Devlin MM, Lipworth BJ. Subsensitivity to bronchoprotection against adenosine monophosphate challenge following regular once-daily formoterol. Eur Respir J. 1998;12(3):580-4.

57. Elers J, Strandbygaard U, Pedersen L, Backer V. Daily use of salmeterol causes tolerance to bronchodilation with terbutaline in asthmatic subjects. Open Respir Med J. 2010;4:48-50.

58. Carroll WD, Jones PW, Boit P, Clayton S, Cliff I, Lenney W. Childhood evaluation of salmeterol tolerance-a double-blind randomized controlled trial. Pediatr Allergy Immunol. 2010;21(2 Pt 1):336-44.

59. Bleecker ER, Postma DS, Lawrance RM, Meyers DA, Ambrose HJ, Goldman M. Effect of ADRB2 polymorphisms on response to longacting beta2agonist therapy: a pharmacogenetic analysis of two randomised studies. Lancet. 2007;370(9605):2118-25.

60. Palmer CN, Lipworth BJ, Lee S, Ismail T, Macgregor DF, Mukhopadhyay S. Arginine-16 beta2 adrenoceptor genotype predisposes to exacerbations in young asthmatics taking regular salmeterol. Thorax. 2006;61(11):940-4.

61. Wechsler ME, Kunselman SJ, Chinchilli VM, Bleecker E, Boushey HA, Calhoun WJ, et al. Effect of beta2-adrenergic receptor polymorphism on response to longacting beta2 agonist in asthma (LARGE trial): a genotype-stratified, randomised, placebo-controlled, crossover trial. Lancet. 2009;374(9703): 1754-64.

62. Raffestin B, Cerrina J, Boullet C, Labat C, Benveniste J, Brink C. Response and sensitivity of isolated human pulmonary muscle preparations to pharmacological agents. J Pharmacol Exp Ther. 1985;233(1):186-94.

63. Van Amsterdam RG, Meurs H, Ten Berge RE, Veninga NC, Brouwer F, Zaagsma J. Role of phosphoinositide metabolism in human bronchial smooth muscle contraction and in functional antagonism by betaadrenoceptor agonists. Am Rev Respir Dis. 1990;142(5):1124-8.

64. Jenne JW, Shaughnessy TK, Druz WS, Manfredi CJ, Vestal RE. In vivo functional antagonism between isoproterenol and bronchoconstrictants in the dog. J Appl Physiol. 1987;63(2):812-9.

65. Boterman M, Elzinga CR, Wagemakers D, Eppens PB, Zaagsma J, Meurs $H$. Potentiation of beta-adrenoceptor function in bovine tracheal smooth muscle by inhibition of protein kinase C. Eur J Pharmacol. 2005;516(1):85-92.

66. Boterman $\mathrm{M}$, Smits SR, Meurs H, Zaagsma J. Protein kinase $\mathrm{C}$ potentiates homologous desensitization of the beta2-adrenoceptor in bovine tracheal smooth muscle. Eur J Pharmacol. 2006;529(1-3):151-6.

67. Pyne NJ, Grady MW, Shehnaz D, Stevens PA, Pyne S, Rodger IW. Muscarinic blockade of beta-adrenoceptor-stimulated adenylyl cyclase: the role of stimulatory and inhibitory guanine-nucleotide binding regulatory proteins (Gs and Gi). Br J Pharmacol. 1992;107(3):881-7.

68. Chuang TT, lacovelli L, Sallese M, De Blasi A. G protein-coupled receptors: heterologous regulation of homologous desensitization and its implications. Trends Pharmacol Sci. 1996;17(11):416-21.

69. Kang JY, Rhee CK, Kim JS, Park CK, Kim SJ, Lee SH, et al. Effect of tiotropium bromide on airway remodeling in a chronic asthma model. Ann Allergy Asthma Immunol. 2012;109(1):29-35.

70. Novelli F, Malagrinò L, Dente FL, Paggiaro P. Efficacy of anticholinergic drugs in asthma. Expert Rev Respir Med. 2012;6(3):309-19.

71. Gross NJ. Anticholinergic agents in asthma and COPD. Eur J Pharmacol. 2006;533(1-3):36-9.
72. Westby M, Benson M, Gibson P. Anticholinergic agents for chronic asthma in adults. Cochrane Database Syst Rev. 2004;3:CD003269.

73. Fryer $A D$, Maclagan J. Ipratropium bromide potentiates bronchoconstriction induced by vagal nerve stimulation in the guinea-pig. Eur J Pharmacol. 1987;139(2):187-91.

74. Pera T, Penn RB. Crosstalk between beta-2-adrenoceptor and muscarinic acetylcholine receptors in the airway. Curr Opin Pharmacol. 2014;16:72-81.

75. Liu YH, Wu SZ, Wang G, Huang NW, Liu CT. A long-acting $\beta 2$-adrenergic agonist increases the expression of muscarine cholinergic subtype-3 receptors by activating the $\beta 2$-adrenoceptor cyclic adenosine monophosphate signaling pathway in airway smooth muscle cells. Mol Med Rep. 2015;11(6):4121-8.

76. Moulton BC, Fryer AD. Muscarinic receptor antagonists, from folklore to pharmacology; finding drugs that actually work in asthma and COPD. Br J Pharmacol. 2011;163(1):44-52.

77. Chamberlain DA, Muir DC, Kennedy KP. Atropine methonitrate and isoprenaline in bronchial asthma. Lancet. 1962;2(7264):1019-21.

78. Rodrigo GJ, Rodrigo C. The role of anticholinergics in acute asthma treatment: an evidence-based evaluation. Chest. 2002;121(6):1977-87.

79. Disse B, Reichl R, Speck G, Traunecker W, Rominger KL, Hammer R. Ba 679 BR, a novel long-acting anticholinergic bronchodilator. Life Sci. 1993;52(5-6): $537-44$.

80. Barnes PJ, Belvisi MG, Mak JC, Haddad EB, O'Connor B. Tiotropium bromide (Ba 679 BR), a novel long-acting muscarinic antagonist for the treatment of obstructive airways disease. Life Sci. 1995;56(11-12):853-9.

81. Tiotropium Bromide. U.S. National Library of Medicine, National Center for Biotechnology Information. Open Chemistry database.https://pubchem.ncbi.nlm. nih.gov/compound/tiotropium_bromide\#section=Top Accessed 20 Feb 2017.

82. Barnes PJ. The pharmacological properties of tiotropium. Chest. 2000;117 Suppl 2:63S-6S.

83. Mak JCW, Barnes PJ. Autoradiographic visualization of muscarinic receptor subtypes in human and guinea pig lung. Am Rev Respir Dis. 1990;141:1559-68.

84. Gross NJ. Tiotropium bromide. Chest. 2004;126(6):1946-53.

85. Disse B, Speck GA, Rominger KL, Witek Jr TJ, Hammer R. Tiotropium (Spiriva): mechanistical considerations and clinical profile in obstructive lung disease. Life Sci. 1999;64(6-7):457-64.

86. O'Connor BJ, Towse LJ, Barnes PJ. Prolonged effect of tiotropium bromide on methacholine-induced bronchoconstriction in asthma. Am J Respir Crit Care Med. 1996;154(4 Pt 1):876-80.

87. Terzano C, Petroianni A, Ricci A, D'Antoni L, Allegra L. Early protective effects of tiotropium bromide in patients with airways hyperresponsiveness. Eur Rev Med Pharmacol Sci. 2004;8(6):259-64.

88. Sharma A, Kerstjens HA, Aalbers R, Moroni-Zentgraf P, Weber B, Dahl R. Pharmacokinetics of tiotropium administered by respimat in asthma patients: analysis of pooled data from phase II and III clinical trials. Pulm Pharmacol Ther. 2017:42:25-32.

89. Santus P, Di Marco F, Radovanovic D, Centanni S. Tiotropium: what came after the UPLIFT study. Expert Opin Pharmacother. 2012;13(4):613-18.

90. Tashkin DP, Celli B, Senn S. A 4-year trial of tiotropium in chronic obstructive pulmonary disease. N Engl J Med. 2008;359:1543-54.

91. Santus P, Centanni S, Verga M, Di Marco F, Matera MG, Cazzola M. Comparison of the acute effect of tiotropium versus a combination therapy with single inhaler budesonide/formoterol on the degree of resting pulmonary hyperinflation. Respir Med. 2006;100(7):1277-81.

92. Amin K, Lúdvíksdóttir D, Janson C, Nettelbladt O, Björnsson E, Roomans GM, et al. Inflammation and structural changes in the airways of patients with atopic and nonatopic asthma. BHR Group. Am J Respir Crit Care Med. 2000; 162(6):2295-301.

93. Costa L, Roth M, Miglino N, Keglowich L, Zhong J, Lardinois D, et al. Tiotropium sustains the anti-inflammatory action of olodaterol via the cyclic AMP pathway. Pulm Pharmacol Ther. 2014;27(1):29-37.

94. Holgate ST. The sentinel role of the airway epithelium in asthma pathogenesis. Immunol Rev. 2011;242(1):205-19.

95. Santus P, Radovanovic D, Paggiaro P, Papi A, Sanduzzi A, Scichilone N, et al. Why use long acting bronchodilators in chronic obstructive lung diseases? an extensive review on formoterol and salmeterol. Eur J Intern Med. 2015; 26(6):379-84.

96. Gosens R, Rieks D, Meurs H, Ninaber DK, Rabe KF, Nanninga J, et al. Muscarinic M3 receptor stimulation increases cigarette smoke-induced IL-8 secretion by human airway smooth muscle cells. Eur Respir J. 2009:34(6): 1436-43. 
97. Santus P, Buccellati C, Centanni S, Fumagalli F, Busatto P, Blasi F, et al. Bronchodilators modulate inflammation in chronic obstructive pulmonary disease subjects. Pharmacol Res. 2012;66(4):343-8.

98. Bosnjak B, Tilp C, Tomsic C, Dekan G, Pieper MP, Erb K, et al. Tiotropium bromide inhibits relapsing allergic asthma in BALB/C mice. Pulm Pharmacol Ther. 2014;27(1):44-51.

99. Bühling F, Lieder N, Kühlmann UC, Waldburg N, Welte T. Tiotropium suppresses acetylcholine-induced release of chemotactic mediators in vitro. Respir Med. 2007;101(11):2386-94.

100. Wollin L, Pieper MP. Tiotropium bromide exerts anti-inflammatory activity in a cigarette smoke mouse model of COPD. Pulm Pharmacol Ther. 2010;23(4): 345-54.

101. Pera T, Zuidhof A, Valadas J, Smit M, Schoemaker RG, Gosens R, et al. Tiotropium inhibits pulmonary inflammation and remodelling in a guinea pig model of COPD. Eur Respir J. 2011;38(4):789-96.

102. Yamaya M, Nishimura H, Hatachi Y, Yasuda H, Deng X, Sasaki T, et al. Inhibitory effects of tiotropium on rhinovirus infection in human airway epithelial cells. Eur Respir J. 2012:40(1):122-32.

103. Bos IS, Gosens R, Zuidhof AB, Schaafsma D, Halayko AJ, Meurs H, et al. Inhibition of allergen-induced airway remodelling by tiotropium and budesonide: a comparison. Eur Respir J. 2007;30(4):653-61.

104. Kistemaker LE, Bos IS, Menzen MH, Maarsingh H, Meurs H, Gosens R. Combination therapy of tiotropium and ciclesonide attenuates airway inflammation and remodeling in a guinea pig model of chronic asthma. Respir Res. 2016;17:13

105. Smit M, Zuidhof AB, Bos SI, Maarsingh H, Gosens R, Zaagsma J, et al. Bronchoprotection by olodaterol is synergistically enhanced by tiotropium in a guinea pig model of allergic asthma. J Pharmacol Exp Ther. 2014;348(2): 303-10.

106. Profita M, Bonanno A, Siena L, Bruno A, Ferraro M, Montalbano AM, et al. Smoke, choline acetyltransferase, muscarinic receptors, and fibroblast proliferation in chronic obstructive pulmonary disease. J Pharmacol Exp Ther. 2009;329(2):753-63.

107. Pieper MP, Chaudhary NI, Park JE. Acetylcholine-induced proliferation of fibroblasts and myofibroblasts in vitro is inhibited by tiotropium bromide. Life Sci. 2007:80(24-25):2270-3.

108. Asano K, Shikama Y, Shibuya Y, Nakajima H, Kanai K, Yamada N, et al. Suppressive activity of tiotropium bromide on matrix metalloproteinase production from lung fibroblasts in vitro. Int J Chron Obstruct Pulmon Dis. 2008;3(4):781-9.

109. Asano K, Shikama Y, Shoji N, Hirano K, Suzaki H, Nakajima H. Tiotropium bromide inhibits TGF- $\beta$-induced MMP production from lung fibroblasts by interfering with Smad and MAPK pathways in vitro. Int J Chron Obstruct Pulmon Dis. 2010;5:277-86.

110. Ohta S, Oda N, Yokoe T, Tanaka A, Yamamoto Y, Watanabe Y, et al. Effect of tiotropium bromide on airway inflammation and remodelling in a mouse model of asthma. Clin Exp Allergy. 2010;40(8):1266-75.

111. Thomson NC, Chaudhuri R, Messow CM, Spears M, MacNee W, Connell M, et al. Chronic cough and sputum production are associated with worse clinical outcomes in stable asthma. Respir Med. 2013;107(10):1501-8.

112. Rogers DF. Motor control of airway goblet cells and glands. Respir Physiol. 2001;125(1-2):129-44.

113. Arai N, Kondo M, Izumo T, Tamaoki J, Nagai A. Inhibition of neutrophil elastase-induced goblet cell metaplasia by tiotropium in mice. Eur Respir J. 2010;35(5):1164-71.

114. Holmes PW, Barter CE, Pierce RJ. Chronic persistent cough: use of ipratropium bromide in undiagnosed cases following upper respiratory tract infection. Respir Med. 1992;86:425-9.

115. Pounsford JC, Birch MJ, Saunders KB. Effect of bronchodilators on the cough response to inhaled citric acid in normal and asthmatic subjects. Thorax. 1985;40:662-7.

116. Lowry R, Wood A, Johnson T, Higenbottam T. Antitussive properties of inhaled bronchodilators on induced cough. Chest. 1988;93:1186-9.

117. Cui Y, Devillier $P$, Kuang $X$, Wang $H$, Zhu L, Xu Z, et al. Tiotropium reduction of lung inflammation in a model of chronic gastro-oesophageal reflux. Eur Respir J. 2010;35(6):1370-6.

118. Bolser DC, DeGennaro FC, O'Reilly S, Hey JA, Chapman RW. Pharmacological studies of allergic cough in the guinea pig. Eur $J$ Pharmacol. 1995;277:159-64.

119. Molassiotis A, Bryan G, Caress A, Bailey C, Smith J. Pharmacological and nonpharmacological interventions for cough in adults with respiratory and non- respiratory diseases: a systematic review of the literature. Respir Med. 2010; 104:934-44.

120. Dicpinigaitis PV, Spinner L, Santhyadka G, Negassa A. Effect of tiotropium on cough reflex sensitivity in acute viral cough. Lung. 2008;186:369-74.

121. Birrell MA, Bonvini SJ, Dubuis E, Maher SA, Wortley MA, Grace MS, et al. Tiotropium modulates transient receptor potential V1 (TRPV1) in airway sensory nerves: a beneficial off-target effect? J Allergy Clin Immunol. 2014; 133(3):679-87.

122. Mutolo D, Cinelli E, lovino L, Pantaleo T, Bongianni F. Downregulation of the cough reflex by aclidinium and tiotropium in awake and anesthetized rabbits. Pulm Pharmacol Ther. 2016;38:1-9.

123. Vogelberg $C$, Moroni-Zentgraf $P$, Leonaviciute-klimantaviciene M, Sigmund $\mathrm{R}$, Hamelmann $\mathrm{E}$, Engel $\mathrm{M}$, et al. A randomized dose-ranging study of tiotropium respimat in children with symptomatic asthma despite inhaled corticosteroids. Resp Res. 2015;16:20,

124. Vogelberg C, Engel M, Moroni-Zentgraf $P$, Leonaviciute-klimantaviciene M, Sigmunf R, Downie J, et al. Tiotropium in asthmatic adolescents symptomatic despite inhaled corticosteroids: a randomised dose-ranging study. Respir Med. 2014;108:1268e1276.

125. Kerstjens HA, Disse B, Schroder-Babo W, Bantje TA, Gahlemann M, Sigmund $R$, et al. Tiotropium improves lung function in patients with severe uncontrolled asthma: A randomized controlled trial.J Allergy Clin Immunol. 2011;128(2):308-14.

126. Beeh KM, Kirsten AM, Dusser D, Sharma A, Cornelissen P, Sigmund R, et al. Pharmacodynamics and pharmacokinetics following once daily and twice daily dosing of tiotropium respimat in asthma using standardized sample contamination avoidance. J Aerosol Med Pulm Drug Deliv. 2016;29(5):406-15.

127. Timmer W, Moroni-Zentgraf $\mathrm{P}$, Cornelissen $\mathrm{P}$, Unseld A, Plzzichini E, Buhl R. Once daily tiotropium respimat $5 \mu \mathrm{g}$ is an efficacious $24 \mathrm{~h}$ bronchodilator in adults with symptomatic asthma. Resp Med. 2015;109:329-38.

128. Beeh KM, Moroni-Zentgraf $P$, Ablinger O, Hollaenderova Z, Unseld A, Engel $M$, et al. Tiotropium respimat in asthma: a double blind randomized, dose ranging study in adult patients with moderate asthma. Resp Med. 2014;15:61.

129. Ohta $K$, Ichinose $M$, Tohda $Y$, Engel M, Moroni-Zentgraf $P$, Kunimitsu $S$, et al. Long term once daily tiotropium respimat is well tolerated and maintains efficacy over 52 weeks in patients with symptomatic asthma in Japan: A randomized, placebo controlled study. Plos One. 2015;10(4): e0124109.

130. Dahl R, Engel M, Dusser D, Halpin D, Kerstjens HA, Zaremba-Pechmann L, et al. Safety and tolerability of once-daily tiotropium respimat $\left({ }^{\oplus}\right)$ as add-on to at least inhaled corticosteroids in adult patients with symptomatic asthma: a pooled safety analysis. Respir Med. 2016;118:102-11.

131. Hamelmann E, Bateman ED, Vogelberg C, Szefler SJ, Vandewalker M, Moroni-Zentgraf $\mathrm{P}$, et al. Tiotropium add-on therapy in adolescent with moderate asthma: a 1 year randomized controlled trial. J Allergy Clin Immunol. 2016;138(2):441-450.e8.

132. Hamelmann E, Bernstein JA, Vandewalker M, Moroni-Zentgraf $P$, Verri $D$, Unseld A, Engel M, Boner AL. A rondomised controlled trial of tiotropium in adolescents with severe symptomatic asthma. Eur Respir J. 2017:49(1).

133. Szefler SJ, Murphy K, Harper T 3rd, Boner A, Laki I, Engel M, El Azzi G, Moroni-Zentgraf P, Finnigan $\mathrm{H}$, Hamelmann E. A phase III randomized controlled trial of tiotropium add-on therapy in children with severe symptomatic asthma. J Allergy Clin Immunol. 2017. doi: 10.1016/j.jaci.2017. 01.014 .

134. Huang J, Chen Y, Long Z, Zhou X, Shu J. Clinical efficacy of tiotropium in children with asthma. Pak J Med Sci. 2016;32(2):462-5.

135. Fardon T, Haggart K, Lee DK, Lipworth BJ. A proof of concept study to evaluate stepping down the dose of fluticasone in combination with salmeterol and tiotropium in severe persistent asthma. Respir Med. 2007;101(6):1218-28.

136. Iwamoto H, Yokoyama A, Shiota N, Shoda H, Haruta Y, Hattori N, et al. Tiotropium bromide is effective for severe asthma with noneosinophilic phenotype. Eur Respir J. 2008;31(6):1379-80

137. Peters SP, Kunselman SJ, Icitovic N, Moore WC, Pascual R, Meredes BT, et al. Tiotropium bromide step up therapy for adults with uncontrolled asthma. N Engl J Med. 2010;363:1715-26.

138. Wang K, Tian P, Wang FYY, Liu C. Assessment of second line treatments for patients with uncontrolled moderate asthma. Int J Clin Exp Med. 2015;8(10): 19476-80. 
139. Kerstjens HA, Engel M, Dahl R, Paggiaro P, Beck E, Vandewalker M, et al. Tiotropium in asthma poorly controlled with standard combination therapy. N Engl J Med. 2012;367(13):1198-207.

140. Kerstjens HA, Moroni-Zentgraf P, Tashkin DP, Dahl R, Paggiaro P, Vandewalker $\mathrm{M}$, et al. Tiotropium improves lung function, exacerbation rate, and asthma control, independent of baseline characteristics including age, degree of airway obstruction, and allergic status. Respir Med. 2016;117:198-206.

141. Kerstiens HAM, Casale TB, Bleecker ER, Meltzer EO, Pizzichini E, Schmidt O, et al. Tiotropium or salmeterol as add-on therapy to inhaled corticosteroids for patients with moderate symptomatic asthma: two replicate, doubleblind, placebo-controlled, parallel-group, active-comparator, randomized trials. Lancet Respir Med. 2015;3:367-76.

142. Paggiaro P, Halpin DMG, Buhl R, Engel M, Zubek VB, Blahova Z, et al. The effect of tiotropium in symptomatic asthma despite low to medium dose inhaled corticosteroids: a randomized controlled trial. J Allergy Clin Immunol Pract. 2016:4:104-13.

143. Dahl R, Casale T, Vandewalker M, Schmidt H, Engel M, Moroni-Zentgraf $P$, et al. Once-daily tiotropium respimat reduces risk of severe asthma exacerbation and asthma worsening in symptomatic asthma, independent of allergic and inflammatory status. Chest. 2015;148,4:671A.

144. Israel E, Chinchilli VM, Ford JG, Boushey HA, Cherniack R, Craig TJ, et al. Use of regularly scheduled albuterol treatment in asthma: genotype-stratified, randomised, placebo-controlled cross-over trial. Lancet. 2004;364(9444): 1505-12.

145. Zuurhout MJ, Vijverberg SJ, Raaijmakers JA, Koenderman L, Postma DS, Koppelman GH, et al. Arg16 ADRB2 genotype increases the risk of asthma exacerbation in children with a reported use of long-acting B2agonists: results of the PACMAN cohort. Pharmacogenomics. 2013; 14(16):1965-71.

146. Park HW, Yang MS, Park CS, Kim TB, Moon HB, Min KU, et al. Additive role of tiotropium in severe asthmatics and Arg16Gly in ADRB2 as a potential marker to predict response. Allergy. 2009;64(5):778-83.

147. Bateman ED, Kornmann O, Schmidt P, Pivovarova A, Engel M, Fabbri LM. Tiotropium is noninferior to salmeterol in maintaining improved lung function in B16-Arg/Arg patients with asthma. J Allergy Clin Immunol. 2011; 128(2):315-22

148. Wechsler ME, Yawn BP, Fuhlbrigge AL, Pace WD, Pencina MJ, Doros G, et al. Anticholinergic vs long-acting $\beta$-agonist in combination with inhaled corticosteroids in black adults with asthma: the BELT randomized clinical trial. JAMA. 2015;314(16):1720-30.

149. Abadoglu O, Berk S. Tiotropium may improve asthma symptoms and lung function in asthmatic patients with irreversible airway obstruction: the reallife data. Clin Respir J. 2016;10(4):421-27.

150. Price D, Kaplan A, Jones R, Freeman D, Burden A, Gould S, et al. Long-acting muscarinic antagonist use in adults with asthma: real-life prescribing and outcomes of add-on therapy with tiotropium bromide. J Asthma Allergy. 2015;8:1-13

\section{Submit your next manuscript to BioMed Central and we will help you at every step:}

- We accept pre-submission inquiries

- Our selector tool helps you to find the most relevant journal

- We provide round the clock customer support

- Convenient online submission

- Thorough peer review

- Inclusion in PubMed and all major indexing services

- Maximum visibility for your research

Submit your manuscript at www.biomedcentral.com/submit

) Biomed Central 